\title{
Pulse Combustor Design A DOE Assessment
}

\author{
DOE/NETL-2003/1190
}

July 2003

U.S. Department of Energy

National Energy Technology Laboratory

P.O. Box 880, 3610 Collins Ferry Road

Morgantown, WV 26507-0880

P.O. Box 10940, 626 Cochrans Mill Road

Pittsburgh, PA 15236-0940

West Third Street, Suite 1400

Tulsa, OK 74103-3519

website: www.netl.doe.gov

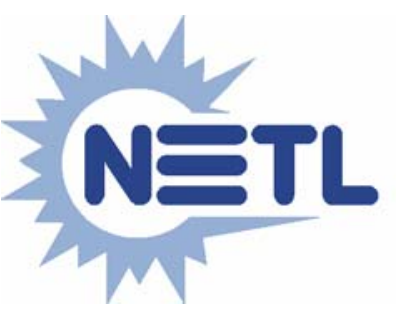




\section{Disclaimer}

This report was prepared as an account of work sponsored by an agency of the United States Government. Neither the United States Government nor any agency thereof, nor any of their employees, makes any warranty, express or implied, or assumes any legal liability or responsibility for the accuracy, completeness, or usefulness of any information, apparatus, product, or process disclosed, or represents that its use would not infringe privately owned rights. Reference therein to any specific commercial product, process, or service by trade name, trademark, manufacturer, or otherwise does not necessarily constitute or imply its endorsement, recommendation, or favoring by the United States Government or any agency thereof. The view and opinions of authors expressed therein do not necessarily state or reflect those of the United States Government or any agency thereof. 


\section{Contents}

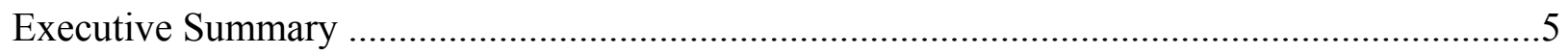

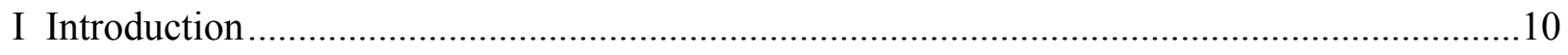

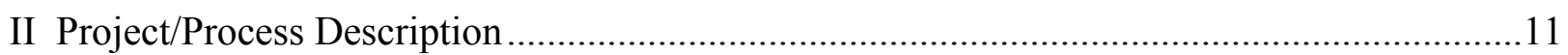

II.A Brief History of the Project.......................................................................... 11

II.B Project Description ................................................................................. 11

II.C Need for the Technology Demonstration......................................................... 12

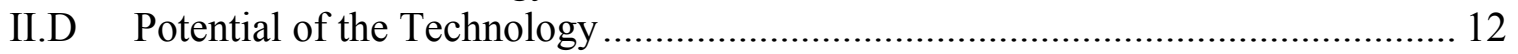

II.E Technology Description................................................................................ 12

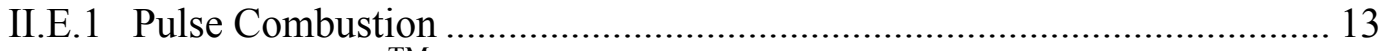

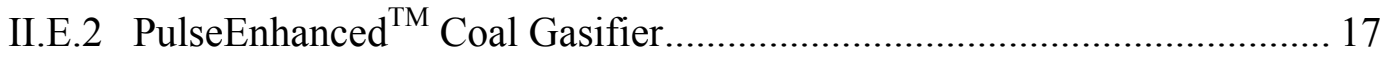

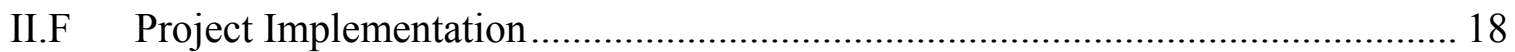

II.F.1 Process Development Unit Test Facility .............................................. 18

II.F.2 Combustor Design Qualification Test Facility ……….............................. 20

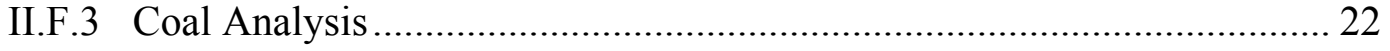

II.G Project Objectives and Statement of Work ………………….......................... 22

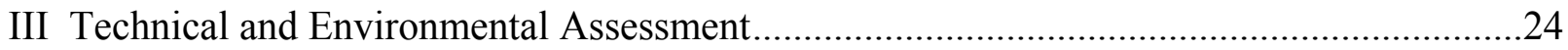

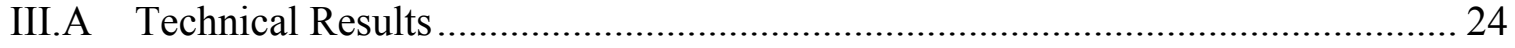

III.A.1 Coal/Steam-Reforming Characterization Tests ......................................... 24

III.A.2 Combustor Qualification Tests ............................................................... 27

III.A.3 Evaluation of Test Results ………………........................................... 31

III.B Environmental Performance …………………............................................... 32

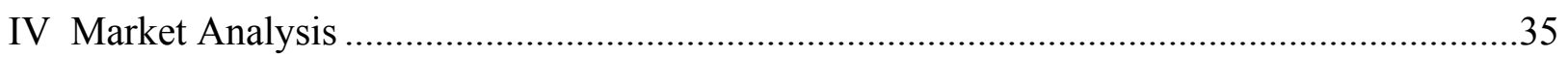

IV.A Market Size/Commercialization …………….............................................. 35

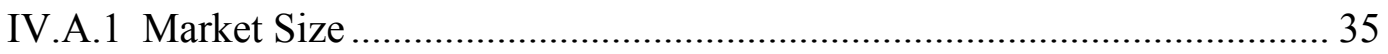

IV.A.2 Commercialization Plan.......................................................................... 37

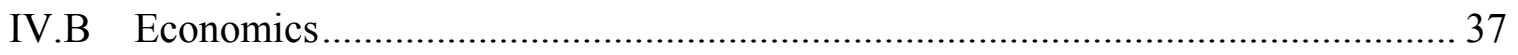

IV.B.1 Capital Costs ................................................................................... 37

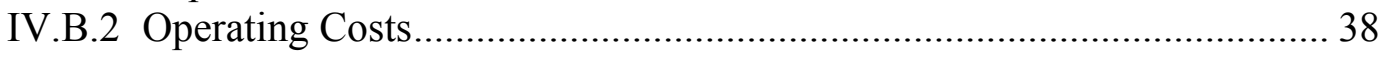

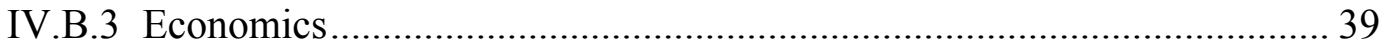

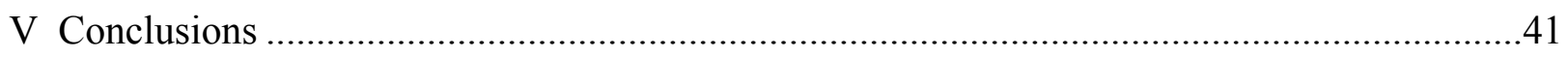

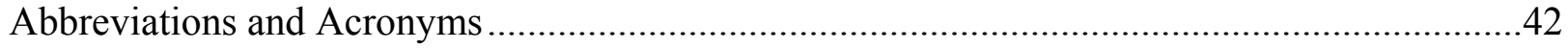

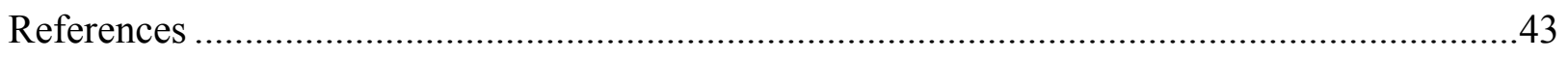

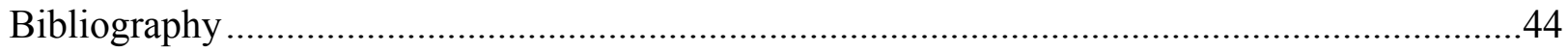




\section{List of Figures and Tables}

Figure $\quad$ Page

1 MTCI PulseEnhanced ${ }^{\mathrm{TM}}$ Coal Gasifier Flow Diagram ............................................... 13

2 Helmholtz-Type Pulse Combustor With an Aerodynamic Air-inlet Valve........................ 14

3 Schematic of Pulse Combustor Operation .................................................................... 15

4 Theoretical Heat-Transfer Coefficients Under Non-Pulsed Conditions Compared to Measured Data in Pulsed Fire Tubes .......................................................................... 17

5 Schematic of PDU Test Facility .............................................................................. 19

6 Block Flow Diagram of Combustor Design Qualification Test Facility ........................... 21

7 Gasifier Pulse Combustor Module ...................................................................................... 21

8 Fraction of Heat Transferred as a Function of Firing Rate .............................................. 31

9 Schematic Drawing of 300 Tons/Day Gasifier ........................................................... 33

Table $\quad$ Page

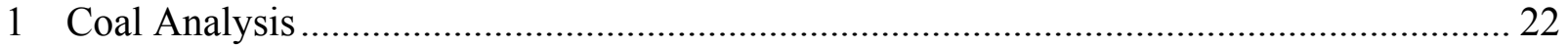

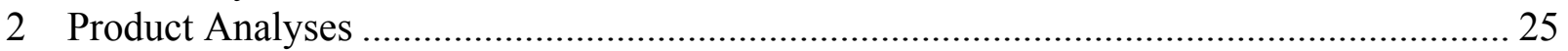

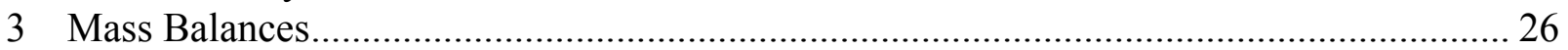

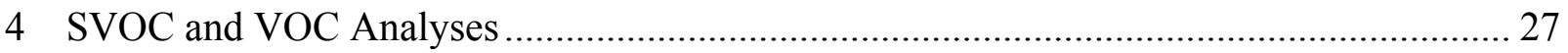

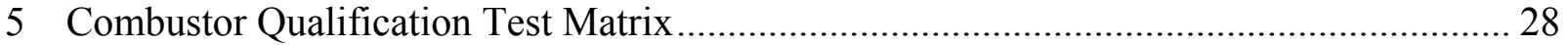

6 Qualification Test Configurations ............................................................................ 28

7 Combustor Qualification Test Results for Series 2 and 3 ........................................... 30

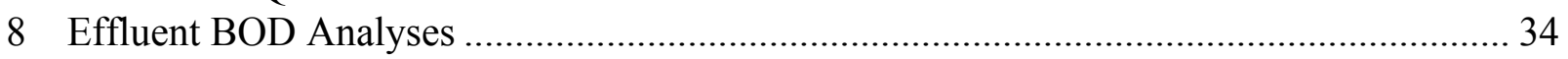

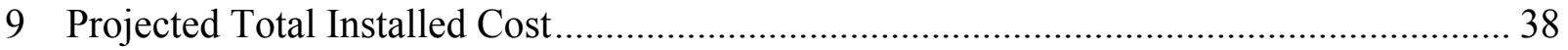

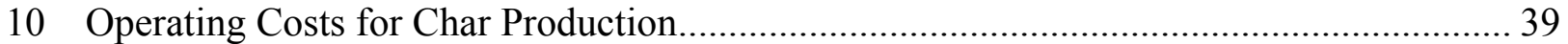

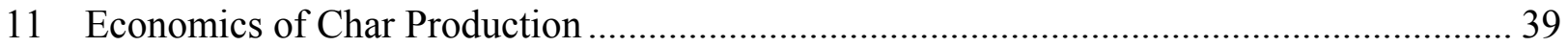

12 Sensitivity of Char Cost to Changes in Project Variables .............................................. 40 


\section{Executive Summary}

This document serves as a U.S. Department of Energy (DOE) post-project assessment (PPA) for the Pulse Combustor Design Qualification Test Clean Coal Technology (CCT) project, submitted by ThermoChem, Inc. (TCI) and selected in Round IV of the CCT Demonstration Program. The site of the project was TCI's facilities in Baltimore, Maryland. Its dual objectives were to test a single 253-resonance-tube combustor in a fluidized sand bed and to study coal gasification in a process development unit (PDU). DOE provided 50 percent of the total project funding of $\$ 8.6$ million.

The Manufacturing and Technology Conversion International (MTCI) PulseEnhanced ${ }^{\mathrm{TM}}$ Coal Gasifier combines two technologies: resonance-tube pulse combustion and fluidized-bed steam reforming of coal or other carbonaceous fuel. The process involves steam reforming of coal to produce syngas, which can be used as a fuel, and char, which can be used in the direct reduction of iron ore (DRI) or as a fuel, in an arrangement which avoids the need for an oxygen plant. Eliminating the requirement for pure oxygen is accomplished by installing a resonance-tube combustor in the fluidized-bed reformer, thus incorporating an innovative indirect heating process to provide the heat required for the endothermic steam gasification of coal. Because of the scope reduction that occurred for this project, the 253-tube pulse combustor was tested only in a sand bed, and not in a fluidized coal bed.

The pulse combustor used in this project consisted of an aerodynamic air-inlet valve, a combustion chamber, and a tailpipe (resonance tube). This combustor configuration is inherently reliable, because it has no moving parts (flapper valves). It is especially suitable for the combustion of coal and other solid fuels, since these fuels can quickly erode valve surfaces. The claimed benefits of pulse combustion include enhanced heat-release rates in the combustion chamber and increased heat-transfer rates in the resonance tubes. In a fluidized bed, the heattransfer coefficient between the fire tubes and the fluidized-bed material is reasonably high. Therefore, the low heat-transfer rate of conventional fire tubes used to heat fluidized-bed reactors is mainly the result of the low heat-transfer coefficient on the flue-gas side of the fire tube. TCI claims that the flue-gas-side heat-transfer coefficient in the pulse combustor is significantly improved. The increased heat-transfer coefficient is probably caused by flue-gas oscillations resulting in a reduction in the boundary layer inside the tube.

In steam reforming of coal, a fluidized bed of powdered coal is contacted with steam at an elevated temperature. Under these conditions, two basic endothermic reactions take place: pyrolysis and carbon/steam reforming. In most gasification processes, the endothermic heat of reaction is provided by burning some of the product with introduced oxygen. In the PulseEnhanced ${ }^{\mathrm{TM}}$ Coal Gasifier used in this project, heat is supplied indirectly from pulse combustors immersed in the fluidized bed to produce a hydrogen-rich, medium-Btu fuel gas without the need for an oxygen plant.

The principal objectives of the project were to perform qualification testing of a 253-tube pulse combustor and to demonstrate its readiness for commercial deployment and to run gasification test in a PDU. 
Tests were conducted in two separate facilities to develop data required to commercialize the pulse-combustor technology. Full-scale heater performance was assessed in the Combustor Design Qualification Test Facility, and the steam reforming of coal was tested in a PDU having a nominal feed capacity of 30 to $50 \mathrm{lb} / \mathrm{h}$ of coal. The PDU reformer is an 8-in. diameter stainlesssteel vessel. Fluid bed height is approximately 6 feet. Two U-shaped pulse-combustor resonance tubes are installed vertically through the bottom of the reformer vessel. The resonance tubes are made of 1.5-in. diameter pipe, approximately $10 \mathrm{ft}$ in length (the same length as used in the fullscale combustor). However, since the resonance tubes are U-shaped, they occupy only $5 \mathrm{ft}$ of the bed height.

The production of char suitable for use in DRI guided the selection of the coal to be tested in the PDU. This selection was made in conjunction with Northshore Mining. In applications in which char production is a major goal, the primary control variable is operating temperature. The objective of the PDU tests was to identify the lowest temperature at which char with a satisfactory sulfur and volatile matter content, suitable for DRI, could be achieved. Mass and energy balances were performed for each steady-state PDU test. Elemental closures were acceptable, considering the size of the equipment. The amount of carbon and sulfur in the char decreased with increasing temperature, and the condensate contained a lower fraction of carbon as temperature increased. In order to maximize char production, operation at 1,000 to $1,100{ }^{\circ} \mathrm{F}$ is preferred, and char suitable for DRI is generated in this temperature range.

Although the production of char for DRI guided gasifier operations in this project, this is not the only opportunity for this technology. More promising opportunities appear to be gasification of coal for syngas production without the need for pure oxygen, and gasification of black liquor from pulp and paper production.

In the Combustor Design Qualification Test Facility, sand, fluidized with air, was used as the fluid bed medium. Water was injected into the bed to impose a heat load on the system to maintain the desired bed temperature. The off-gas, comprised of air used for fluidization and steam generated in the fluid-bed, is passed through a cyclone for particulate removal before exiting to the atmosphere. Performance characteristics of a full-scale, multiple-resonance-tube pulse combustor were determined in this test facility. The combustor was fired on natural gas for most of the testing program, with a short test, burning simulated syngas. The amount of heat supplied by the pulse combustor was determined at several firing rates and excess-air levels, which were the main variables examined.

From the data collected, an energy balance, the amount of heat transferred to the bed, and the tube-to-bed heat-transfer coefficient could be calculated. The pulse combustor operated well with strong pulsation and air suction. Self-aspiration increased significantly with firing rate. The pulsation frequency was generally on the order of $58 \mathrm{~Hz}$. The sound pressure level varied from $165 \mathrm{~dB}(\sim 1.5$ psi peak-to-peak pressure fluctuation) at a 6 million British thermal units per hour (MBtu/h) firing rate to about $173 \mathrm{~dB}$ ( 4 psi peak-to-peak pressure fluctuation) at a $20 \mathrm{MBtu} / \mathrm{h}$ firing rate. The thermal response of the bed to pulsed heating was quite rapid with bed heatup rates in the range 50 to $200^{\circ} \mathrm{F} / \mathrm{h}$. The nominal bed temperature during the run was on the order 
of $1,000^{\circ} \mathrm{F}$, while the peak temperature reached was $1,100^{\circ} \mathrm{F}$. Pulse-combustion-chamber temperature averaged about $2,400^{\circ} \mathrm{F}$. Flue gas from the combustor was monitored by a continuous emissions monitoring system.

Although raw data were presented for the six test series conducted, only results from Test Series 2 and 3 were worked up and presented in reduced form in the Final Report. TCI has indicated that the purpose of Series 1 was only to shake down the system and that Series 2 and 3 are most applicable to low-temperature char production for DRI, which was the focus of the program. The amount of heat transferred to the bed was reported, but heat-transfer coefficients were not reported, even though the Final Report states that they were calculated. To get a feel for the improvement in heat transfer resulting from pulse combustion, overall heat-transfer coefficients were calculated based on the data presented. It appears that the heat-transfer coefficient inside a pulsed tube may be 2 to 2.5 times higher than for a non-pulsed tube. TCI has stated that heattransfer coefficients that are reported to be as high as 3 to 5 times greater than a non-pulsed fire tube refer to the local region early in the resonance bundle.

The tests on the full-scale combustor were carried out in a sand bed, quenched with water to maintain temperature control. This is a considerably different and much cleaner environment than would exist if the bed consisted of coal and char particles. Thus, no information was gathered on the tendency of the 253-tube bundle to foul or the effect fouling would have on the heat-transfer coefficient. TCI has indicated that they did not observe fouling in tests on black liquor from the pulp and paper industry and believe that this indicates that fouling will not occur with coal. They also indicate that no fouling was observed in the two-tube PDU.

Although the indirectly heated steam/coal gasifier may have commercial applications, it was not possible, by the end of the project, based on the limited number of tests conducted, to clearly determine the advantage of this technology. Further testing is needed to evaluate pulsecombustor applications. TCI may have additional information bearing on this issue that was not presented in the final report.

Assessing the potential environmental benefits for a new technology requires consideration of a broad range of parameters, including air and water emissions, hazardous material issues, generation of solid wastes, federal environmental regulations, state permitting requirements, and local regulations. There are some scaleup issues that need to be considered prior to commercialscale replication of the pulse-combustor technology.

Although, because of its small scale, no environmental impacts were associated with this project, several potential problem areas need to be addressed. Concerns include the volume and nature of the solid and liquid wastes produced, air emissions stemming from the process, and noise pollution. More information may need to be generated to fully assess the impact in these areas.

Noise, often governed by local ordinances, needs to be carefully considered. Ambient noise levels will have to be estimated. The scaled-up version of the pulse combustor, with multiple 253-tube bundles, could emit a substantial amount of noise, if fired without appropriate noise abatement measures. If decibel levels are above Occupational Safety and Health Administration (OSHA) or 
community standards, effective noise mitigation measures will have to be implemented. TCI has indicated that the MTCI/TCI design incorporates acoustic muffling measures in the air-inlet plenum and the exhaust decoupler. Also, tandem arrangement, or pairing of two combustors to run 180 degrees out of phase to cancel out noise emissions, is being considered. According to TCI, designs for commercial applications have a target for noise emissions of less than $85 \mathrm{~dB}$ at $3 \mathrm{ft}$.

Impurities in the process condensate, the only wastewater stream generated in this process, were reported. Biological oxygen demand (BOD) is one of the concerns with this effluent. Although raw effluent could not be discharged directly into a stream, conventional aerobic digestion technology should provide adequate treatment to address the BOD problem. However, additional investigation into the adequacy of conventional aerobic digestion for complete removal of other harmful constituents would be needed to ensure that this discharge was environmentally acceptable. The technology produces char, tars, and fuel gas when operating for the mild gasification of coal. Although yields of tars and volatile organic compounds were measured in the PDU, how to treat these materials in a commercial unit needs to be addressed prior to replication of the technology to ensure that these waste streams are properly handled.

The initial technology concept was to produce char for use in DRI. However, in addition, TCI has proposed several other potential applications, including black-liquor processing and chemical recovery; hazardous, low-level mixed-waste volume reduction and destruction; coal processing for the production of hydrogen and syngas; coal-pond waste and coal rejects processing; and feeding a range of other fuels and wastes to produce a variety of value-added products.

Because the scope of work of this project focused on char production for DRI, and because the technology is in an early stage of development with only limited data available, it is difficult to judge the market for potential applications. The Final Report provides data on only one coal, which was already low sulfur (0.38 percent). Coal/steam reforming was only performed in the PDU, while the commercial-scale pulse combustor only operated with a sand bed. Therefore, we don't know if the pulse tubes would foul when exposed to coal, or if other problems would arise.

Furthermore, for applications where the main product is syngas, either a concurrent market for char needs to exist, or else complete coal gasification needs to occur. Complete gasification has not been demonstrated, so considerable additional development work is required before opportunities to supply syngas can be seriously considered. A potential market for the destruction of hazardous wastes would also require further development, since such wastes generally require very high levels of destruction, and such high conversion levels are difficult to achieve at the reported gasifier temperatures. It would have to be demonstrated that the TCI technology can accomplish this, although TCI asserts that it has data from another project bearing on this issue (but these data were not included in the Final Report).

Commercialization would include working with a recognized company, such as Midrex, which has extensive experience and contacts within the steel and related industries. Midrex's technical in-house capabilities would provide the innovative MTCI steam-reforming process with valuable design and operating experience for construction and operation of the first plant. Midrex and 
ThermoChem have initiated discussion to explore areas of mutual interest.

Capital-cost estimates are only preliminary because of lack of data from a full-scale unit. The projected cost for a commercial plant for mild gasification of sub-bituminous coal to provide char for the Northshore Mining Company was made based on a budget estimate performed by Industra in July 1997. The plant is based on a reactor with five 253-tube pulse combustors having a nominal coal processing (mild gasification) capacity of $40 \mathrm{tons} / \mathrm{hr}$, operating at a 90 percent capacity factor. The total estimated installed cost for the plant is $\$ 28.2$ million. Estimated operating costs (including by-product credit) are $\$ 3.2$ million/yr. This gives an estimated cost of char of $\$ 82.29 /$ ton (current dollars) or $\$ 63.19 /$ ton (constant dollars). These costs are somewhat less than the cost of coke at about $\$ 95$ to $\$ 115 /$ ton.

This project provided the first step for potential commercialization of the TCI technology involving indirectly heated gasification using a pulsed combustor as the heat source. This project generally met its objective of demonstrating the operability of a pulsed combustor. However, because the project only involved testing one 253-tube pulse combustor installed in a sand bed and some PDU studies of coal/steam gasification, these tests, although indicating potential, do not provide enough data to make a sound judgment on possible applications of the technology. 


\section{Introduction}

The goal of the U.S. Department of Energy's (DOE) Clean Coal Technology (CCT) program is to furnish the energy marketplace with a number of advanced, more efficient, and environmentally responsible coal utilization technologies through demonstration projects. These projects seek to establish the commercial feasibility of the most promising advanced coal technologies that have developed beyond the proof-of-concept stage.

This document serves as a DOE post-project assessment (PPA) of a project selected in CCT Round IV, the Pulse Combustor Design Qualification Test, as described in a Report to Congress (U.S. Department of Energy 1992). Pulse combustion is a method intended to increase the heattransfer rate in a fired heater. The desire to demonstrate the use of pulse combustion as a source of heat for the gasification of coal, thus avoiding the need for an oxygen plant, prompted ThermoChem, Inc. (TCI), to submit a proposal for this project. In October 1992, TCI entered into a cooperative agreement with DOE to conduct this project. In 1998, the project was restructured and scaled down, and in September 1998, a new cooperative agreement was signed. The site of the revised project was TCI's facilities in Baltimore, Maryland. The original purpose of this CCT project was to demonstrate a unit that would employ ten identical 253-resonancetube combustors in a coal gasification unit. The objective of the scaled-down project was to test a single 253-resonance-tube combustor in a fluidized sand bed, with gasification being studied in a process development unit (PDU). DOE provided 50 percent of the total project funding of $\$ 8.6$ million.

The design for the demonstration unit was completed in February 1999, and construction was completed in November 2000. Operations were conducted in March 2001. The independent evaluation contained herein is based primarily on information from TCI's Final Report (ThermoChem 2002a, 2002b) and Test Plan (ThermoChem 2000), as well as other references cited. 


\section{Project/Process Description}

\section{II.A Brief History of the Project}

This project involves the combination of two technologies: pulse-tube combustion and indirectly heated gasification. About 1991, ThemoChem and Weyerhaeuser Paper Company conducted a demonstration project at Weyerhaeuser's plant in New Bern, North Carolina, that involved the gasification of 50 tons/day of black-liquor solids. The CCT project, as originally proposed, was to scale up the technology to commercial size of 300 tons/day of black-liquor solids at Weyerhaeuser's facilities in Springfield, Oregon. However, after this site was selected, Weyerhaeuser signed a contract for low-cost natural gas at its Springfield plant and requested a delay in the project, so it could profit from its natural gas contract. The CCT project was also going to provide fuel gas to Weyerhaeuser. Rather than delay the project, the site was relocated.

The new site was at the Caballo Rojo Mine in Gillette, Wyoming. The gas produced by gasification of coal from the mine was to be burned for power production by Wisconsin Power and Light, and the by-product steam was to be used in a K-Fuel ${ }^{\mathrm{TM}}$ plant in a process to upgrade sub-bituminous coal. The K-Fuel ${ }^{\mathrm{TM}}$ plant was to be built with private money, with no DOE costshare funds. This project configuration is discussed in the Report to Congress (U.S. Department of Energy 1992). However, issues arose with financing, necessitating another site change.

In 1994, the site was changed to Northshore Mining Company's facilities in Silver Bay, Minnesota. However, all the necessary requirements could not be completed in the scheduled time and in 1998, the project was completely restructured and scaled down, a new Cooperative Agreement was signed, and the project was relocated to ThemoChem's facilities in Baltimore, Maryland. The revised project involved testing the heat-transfer capabilities of one 253-tube pulse combustor, which had been built during an earlier phase of the project, plus some coal gasification work conducted on a PDU.

\section{II.B Project Description}

The original objective of this project was to demonstrate Manufacturing and Technology Conversion International's (MTCI) PulseEnhanced ${ }^{\mathrm{TM}}$ Coal Gasifier. This technology was developed with DOE support through a Small Business Innovative Research (SBIR) Program and subsequent cooperative research and development agreements. When the scope of the project was reduced, the objective was changed to qualification testing of one commercial-size pulse-tube combustor in a fluidized bed of sand plus testing coal/steam gasification in a PDU. Thus, the project consisted of operating two units, a 253-tube unit tested only for combustion characteristics and heat-transfer properties, and a PDU with two pulse tubes in which coal gasification was tested.

The technology involves steam reforming of coal (see section II.E.2) to produce syngas, which 
can be used as a fuel, and char, which can be used in the direct reduction of iron ore or as a fuel, in an arrangement which avoids the need for an oxygen plant. Eliminating the requirement for pure oxygen is accomplished by using a gasifier that is heated indirectly using a pulse-tube combustor. Hot combustion gases pass through the pulse tubes, which are immersed in a fluidized bed of coal in the gasifier. Pulse combustion is claimed (Durai-Swamy et al. 1994) to increase the heat-transfer coefficient by a factor of up to three to five, making it practical to indirectly heat a gasifier. Because of the scope of reduction that occurred, the 253-tube pulse combustor was tested only in a sand bed, and not in a fluidized bed of coal.

\section{II.C Need for the Technology Demonstration}

In previous work, 61-tube and 72-tube bundles were tested, but these sizes are too small for any significant commercial applications. Any commercial application of this technology will involve using multiple 253-resonance-tube bundles. Therefore, qualification of this bundle size is critical for future commercialization of this technology. It is also necessary to understand the behavior of a coal/steam gasifier in which heat is supplied by a pulse-tube bundle immersed in a fluidized bed of coal. Therefore, the PDU work is also needed for eventual commercialization. What is further needed (and not demonstrated in this project) is the operation of the 253-tube pulse combustor in a fluidized bed of coal.

\section{II.D Potential of the Technology}

One of the major expenses of coal gasification is the cost of oxygen. Not only is the capital cost of the oxygen plant a major fraction of total capital cost, but operating costs are also significant. An indirectly heated gasifier, with heat supplied by a pulse combustor, obviates the need for an oxygen plant. Thus, this technology has the potential to provide less expensive syngas. However, a concomitant product of the syngas generated by this technology is char. Therefore, a market for the char is necessary for this technology to be successful. Potential markets for char are for use as a fuel in the direct reduction of iron ore (DRI).

\section{II.E Technology Description}

The MTCI PulseEnhanced ${ }^{\mathrm{TM}}$ Coal Gasifier is a combination of two technologies: resonance-tube pulse combustion and fluidized-bed steam reforming of coal or other carbonaceous fuel. (See Figure 1.) In the PulseEnhanced ${ }^{\mathrm{TM}}$ Coal Gasifier, the resonance-tube combustors are installed in the fluidized-bed reformer, thus incorporating an innovative indirect heating process to provide the heat required for the endothermic steam gasification of coal. The technologies involved are described in the following sections. 


\section{II.E.1 Pulse Combustion}

Pulse combustion involves combustion-induced flow oscillations produced intentionally through the equipment design. Pulse combustors can be divided into two general classes: those in which the pulsations occur naturally because of combustion-induced instability, and those that

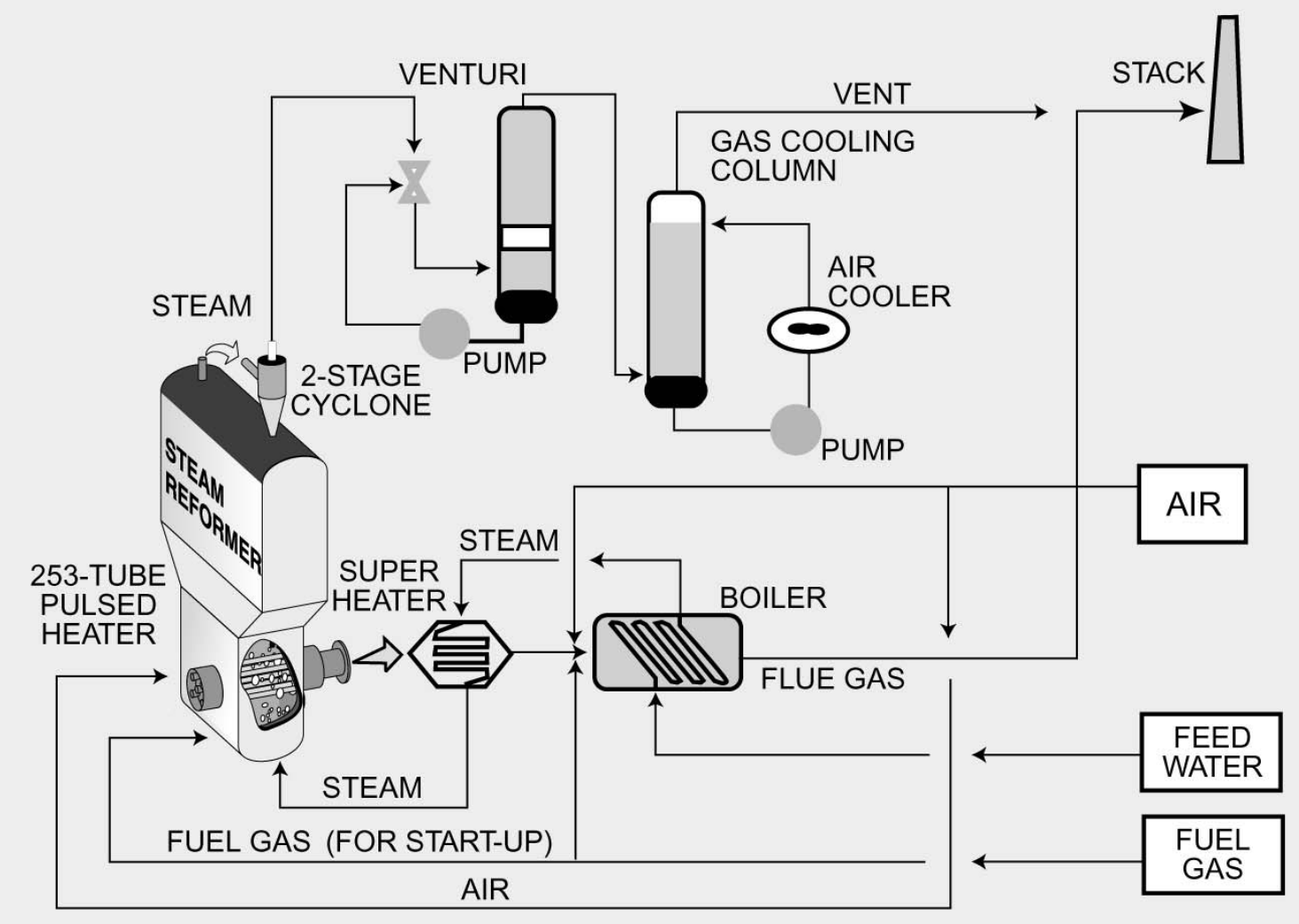

Figure 1. MTCI PulseEnhanced ${ }^{\mathrm{TM}}$ Coal Gasifier Flow Diagram

require an external device, such as a spark plug or a flapper valve, to maintain the pulsecombustion process. The combustor used in this project belongs to the first of these classes. This class of combustors, which can be referred to as self-induced or resonating-pulse combustors, can be divided further into three types: Helmholtz, Schmidt, and Rijke, depending upon the configuration of the combustor and the characteristics of the oscillations.

The pulse combustor employed in the MTCI and ThermoChem equipment is the Helmholtz type. (See Figure 2.) The basic Helmholtz configuration consists of an aerodynamic air-inlet valve, a combustion chamber, and a tailpipe (resonance tube). This combustor configuration is inherently reliable, because it has no moving parts (flapper valves). It is especially suitable for the combustion of coal and other solid fuels, since these fuels can quickly erode valve surfaces. 


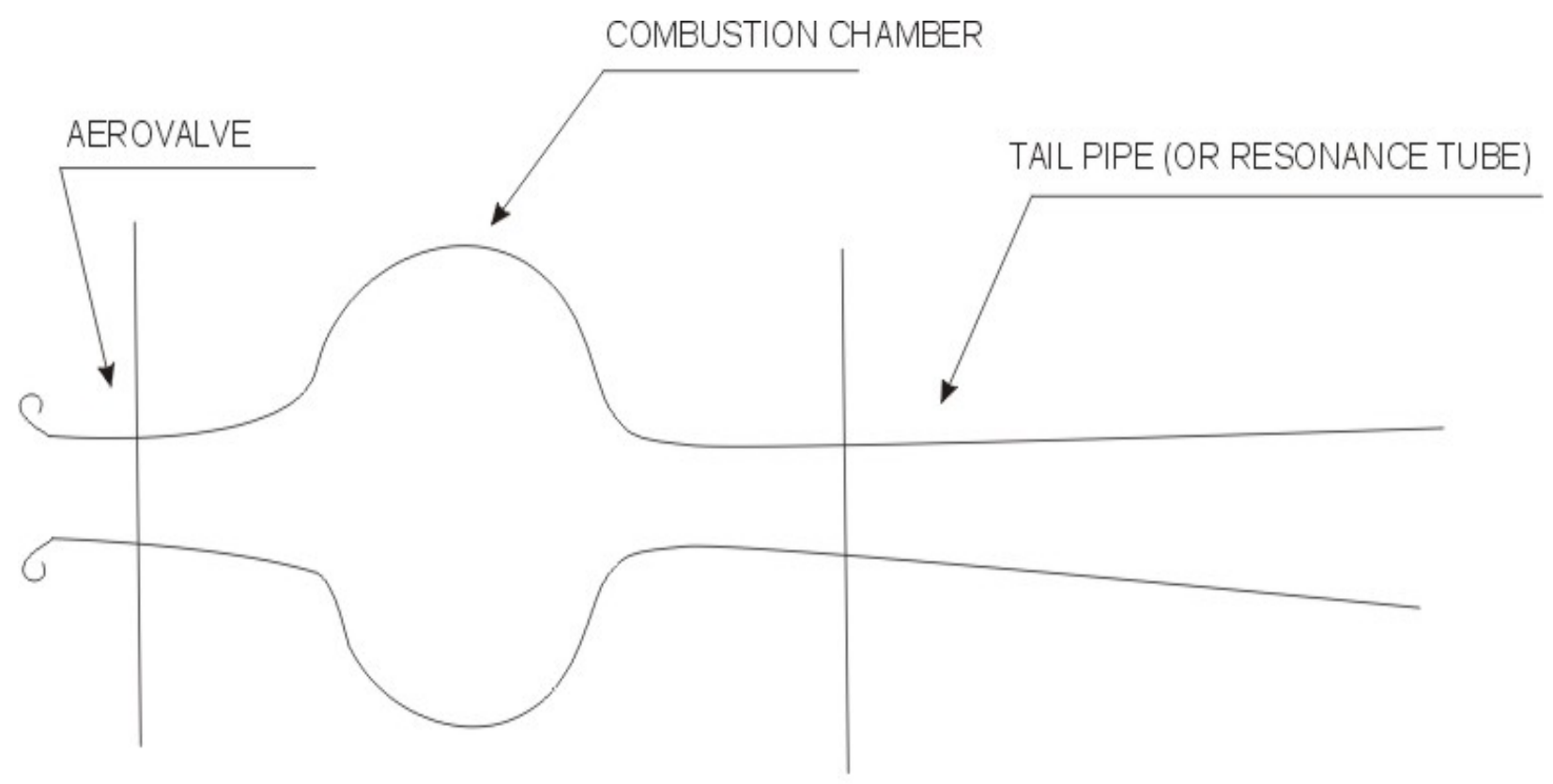

Figure 2. Helmholtz-Type Pulse Combustor With an Aerodynamic Air-inlet Valve

A pulse-combustion cycle can be compared to a four cycle internal combustion engine, but without any moving parts. (See Figure 3.) First, air and fuel are drawn into the combustion chamber with an increase in pressure. Next, the air/fuel mixture is ignited (initially by spark, but later by the heat of the chamber walls), resulting in expansion. An MTCI-patented aerovalve prevents the combustion products from leaking from the combustion chamber and directs the hot gases through the resonance tubes. The aerovalve is designed to permit easy entry of air into the combustion chamber, and also provide a barrier to the exit of combustion gases. As the combustion products leave the combustion chamber, fresh fuel and air are drawn in, and the cycle repeats. Thus, the process repeats autogenously, subject to the frequency resulting from the specific geometry of the pulse combustor.

The claimed benefits of pulse combustion (Durai-Swamy et al. 1994) include enhanced heatrelease rates in the combustion chamber and increased heat-transfer rates in the resonance tubes. The efficiency of a coal-burning furnace depends upon the rate at which oxygen diffuses to the coal surface. During combustion, a boundary layer of products of combustion (water vapor and carbon oxides) builds up around the particles and acts as an oxygen diffusion barrier. This is particularly important as the coal particles burn and become smaller and more ash laden and the oxygen concentration in the surrounding gas decreases. 


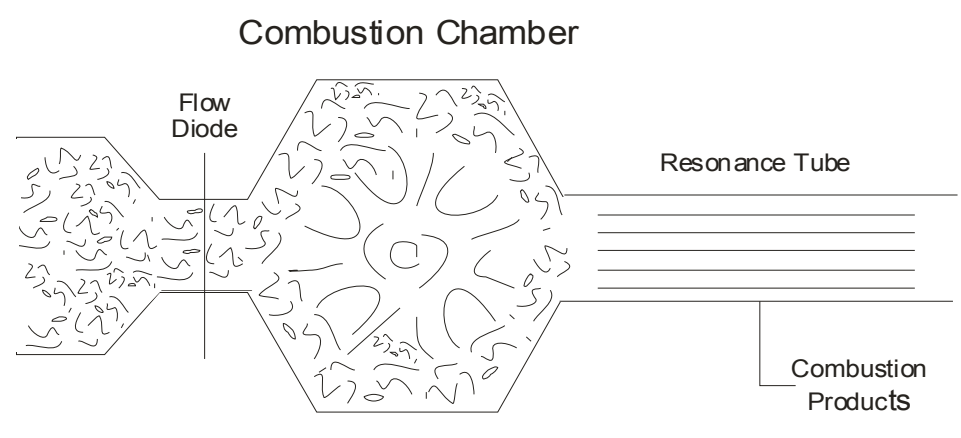

A. Ignition and Combustion

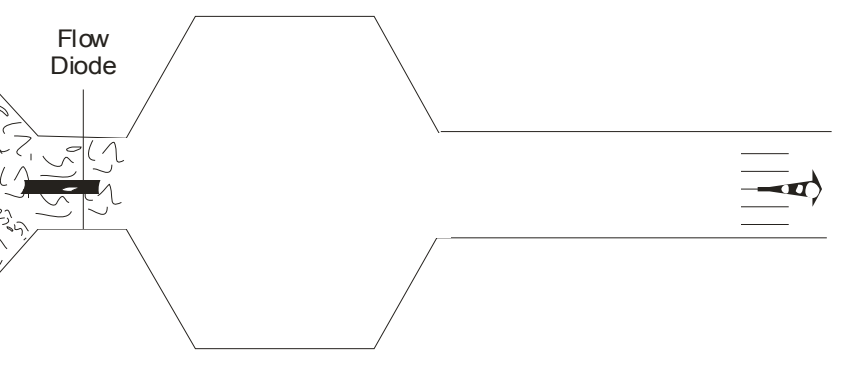

C. Purge and Recharge

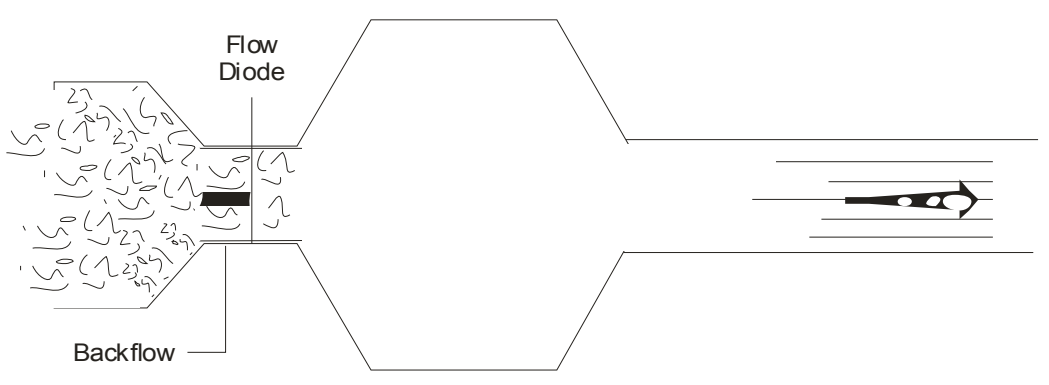

B. Expansion

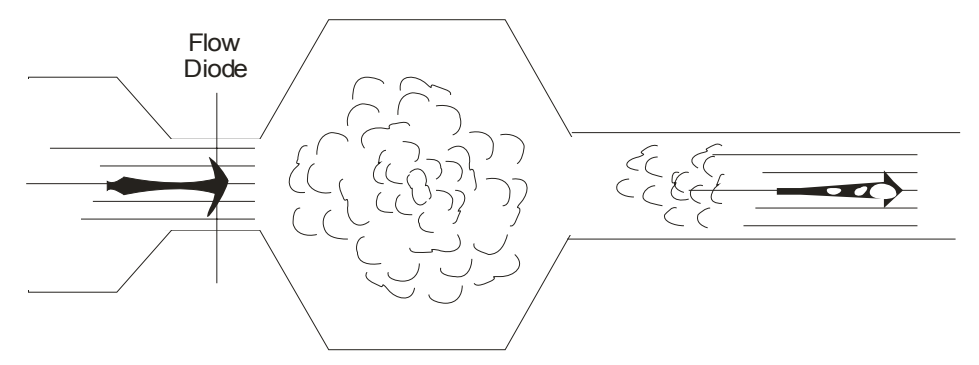

D. Recharge and Compress

Figure 3. Schematic of Pulse Combustor Operation 
In a Helmholtz pulse combustor, as the burning coal particles flow down the resonance tube, the amplitude of the oscillatory velocity increases and causes vigorous relative oscillatory motion between the burning particle and the surrounding gas. This causes the diffusion barrier around the burning particle to be swept away, thus increasing diffusion of oxygen to the particle and resulting in high carbon burnout and a high heat-release rate. Another benefit is that combustion continues in the pulse tubes, thus providing a more uniform temperature in the tubes.

This theory applies only to the combustion of solid fuels. With gaseous fuels, which burn much faster, this theory would not appear to be applicable. Also, when solid fuels are burned, combustion is not complete in the combustor and continues in the pulse tubes themselves, thus providing a more uniform temperature in the tubes. Since maximum temperature is reduced, lower nitrogen oxides $\left(\mathrm{NO}_{\mathrm{x}}\right)$ emissions should result. However, with gaseous fuel, most of the combustion should occur in the combustion chamber.

For a commercial operation, a single resonance tube will not have sufficient surface area to transfer all the heat necessary to the fluid bed. Therefore, multiple parallel resonance tubes, arranged in a suitable pattern, must be used. To scale up a pulse combustor, the number of parallel resonance tubes is increased, with the result that the ratio of the combustion chamber depth to its diameter is reduced.

It is essential that the oscillatory component of the flow velocity in all the resonance tubes be in phase to achieve strong pulsations and, thus, enhanced heat-transfer and heat-release rates. The larger the number of tubes, the more critical is the tuning of these self-induced, combustiondriven oscillations. Therefore, a number of independent aerodynamic valves are employed to introduce the combustion air to various segments of the combustion chamber. When tuning a multiple-resonance-tube pulse-combustion system, high pulsation amplitudes must be achieved to ensure as even as possible a distribution of the hot flue gases among the resonance tubes. Such distribution is critical to achieving the required heat transfer at the high temperatures necessary for steam reforming of coal.

The low heat-transfer rate of conventional fire tubes used to indirectly heat fluidized-bed reactors is a result of the low heat-transfer coefficient on the flue-gas side of the fire tube, because the heat-transfer coefficient between the fire tube and the fluidized-bed material is reasonably high. In a pulse combustor, the flue-gas side heat-transfer coefficient is claimed to be increased significantly, resulting in an increase in overall heat-transfer rate by a factor of 3 to 5 . Figure 4 compares theoretical heat-transfer coefficients for non-pulsating conditions with data from pulsating fire tubes. The increased heat-transfer coefficient is probably because of a reduction in the boundary layer inside the tube, which is caused by the oscillations in the flue gas. However, it is clear that the 3 to 5 enhancement factor does not apply to the entire tube bundle, since Figure 4 shows an enhancement of only 1.5 to 2. TCI has indicated that the 3 to 5 enhancement occurs mainly in the front section of the tube bundle (Rockvam 2002). 


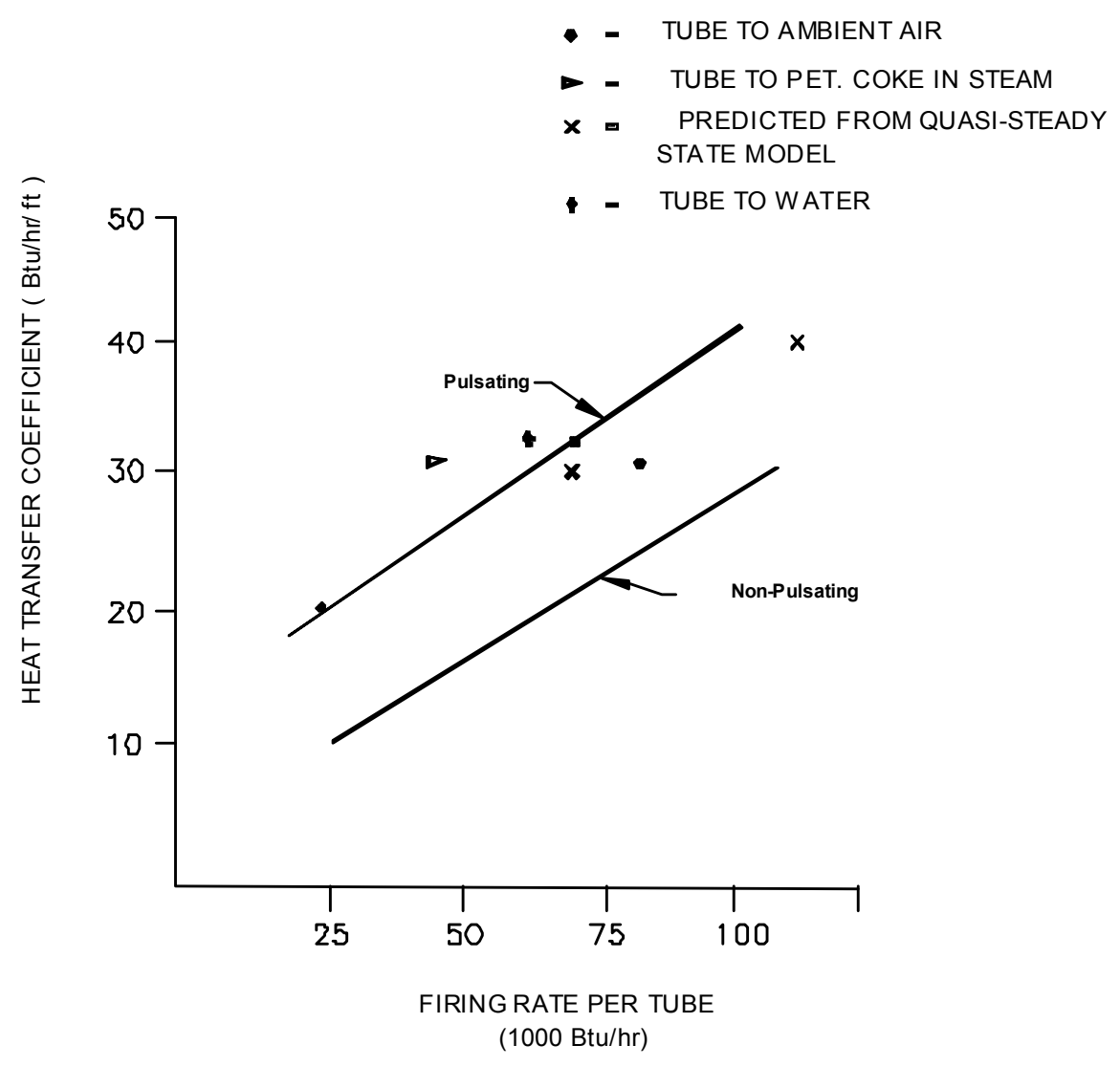

Figure 4. Theoretical Heat-Transfer Coefficients Under Non-Pulsed Conditions Compared to Measured Data in Pulsed Fire Tubes (after Durai-Swamy et al. 1994)

\section{II.E.2 PulseEnhanced ${ }^{\mathrm{TM}}$ Coal Gasifier}

In the steam-reforming process, a fluidized bed of powdered coal is contacted with steam at an elevated temperature. Under these conditions, two basic endothermic reactions take place: pyrolysis and carbon/steam reforming:

$$
\begin{aligned}
& \mathrm{C}_{\mathrm{m}} \mathrm{H}_{\mathrm{n}} \mathrm{O}_{\mathrm{p}} \mathrm{S}_{\mathrm{q}}+\text { heat ----> } \mathrm{aCO}_{2}+\mathrm{bH}_{2} \mathrm{O}+\mathrm{cCH}_{4}+\mathrm{dH}_{2}+\mathrm{eH}_{2} \mathrm{~S}+\mathrm{fC}_{\mathrm{x}} \mathrm{H}_{\mathrm{y}} \\
& \mathrm{C}+\mathrm{H}_{2} \mathrm{O}---->\mathrm{CO}+\mathrm{H}_{2}
\end{aligned}
$$

These reactions are illustrative, and are not precise representations of what occurs. Many other products can result from pyrolysis, and the reaction of steam with coal is more complex than shown. In most gasification processes, the endothermic heat of reaction is provided by introducing oxygen into the gasifier to burn some of the product. In the PulseEnhanced ${ }^{\mathrm{TM}}$ Coal Gasifier used in this project, the heat is supplied indirectly from pulse combustors immersed in the fluidized bed. Steam reforming produces a hydrogen-rich, medium-Btu fuel gas without the need for an oxygen plant to supply pure oxygen. In the MTCI steam-reforming system, a 
multiple-resonance-tube pulse combustor is employed in which the resonance tubes serve as the heat exchanger to deliver heat indirectly to the fluid-bed reactor.

\section{II.F Project Implementation}

The two different units operated as part of this project (PDU Test Facility, and Combustor Design Qualification Test Facility) are described in the following sections.

\section{II.F.1 Process Development Unit Test Facility}

Figure 5 is a schematic diagram of the PDU Test Facility, which consists of the following subsystems:

- $\quad$ Coal metering and injection.

- $\quad$ Steam reformer reactor and two-stage cyclone.

- $\quad$ Steam boiler and feedwater reverse osmosis (RO) unit.

- $\quad$ Two-stage steam superheater.

- $\quad$ Gas chromatograph (GC), instrumentation, and controls (not shown on Figure 5).

The PDU has a nominal feed capacity of 30 to $50 \mathrm{lb} / \mathrm{h}$ of coal. Coal is fed to the reformer reactor by a metering and injection screw system and fluidized with steam. Fluid-bed temperature is maintained at the desired level by regulating the pulse-combustor firing rate. At operating temperature, the feed undergoes a high rate of heating, which promotes rapid pyrolysis and steam reforming. In the absence of free oxygen, the steam reacts endothermically with the coal to produce a medium-Btu syngas rich in hydrogen.

Bed temperature is the main variable that controls char yield and quality. As bed temperature is lowered, the rate of the carbon/steam reaction decreases, and more char is produced. But a reasonably high temperature is needed to reduce the sulfur content of the char and to produce lighter condensable hydrocarbons.

The PDU reformer is an 8-in. diameter stainless-steel vessel. Fluid bed height is approximately 6 $\mathrm{ft}$. Two U-shaped pulse-combustor resonance tubes are installed vertically through the bottom of the reformer vessel. The resonance tubes are made of 1.5 -in. pipe, approximately $10 \mathrm{ft}$ in length, the same length as used in the full-scale combustor. However, since the resonance tubes are Ushaped, they occupy only $5 \mathrm{ft}$ of the bed height. These tubes supply heat to balance the endothermic pyrolysis and steam-reforming reactions. 


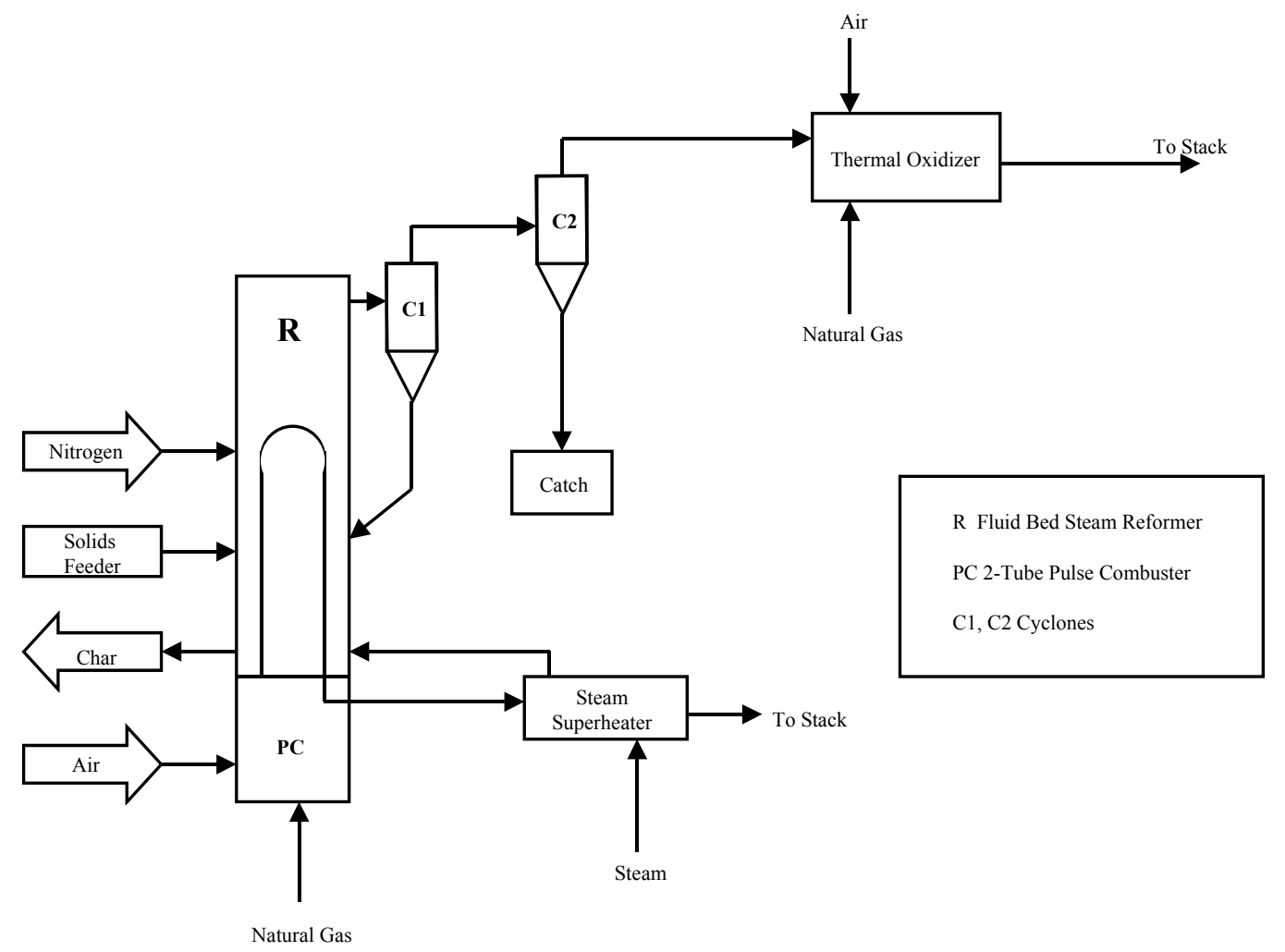

Figure 5. Schematic of PDU Test Facility

The reformer operates slightly above atmospheric pressure. The startup fluid bed is silica sand, fluidized with low-pressure (15 psig) superheated nitrogen. After coal feed is initiated, steam replaces the nitrogen as the fluidizing medium. The reformer operates in the bubbling regime with a low superficial velocity of 0.5 to $1.0 \mathrm{ft} / \mathrm{s}$. The low velocity ensures sufficient gas residence time for reaction.

Because of the pressure differential between the fluid bed reactor and the metering bin, coal from the feed bin is fed to the reformer vessel through a lockhopper. Three variable-speed, paralleldrive, metering screws provide volumetric flow control of the feed to the injection screw. The feed injection point is located near the bottom of the reformer to increase product gas residence time in the bed and permit further reaction. The product gas from the steam reformer passes through two stages of high efficiency cyclones and continues on to a thermal oxidizer. Solids removed in the first cyclone are returned to the reactor through a heated dip leg, while solids removed in the second cyclone are collected in a catchpot. A dry gas sample is sent to a gas chromatograph (GC) for analysis, and the remainder of the product gas is sent to a thermal oxidizer. Char is extracted from the bottom of the fluidized bed. 
A natural-gas-fired boiler supplies 100 psig steam, which is preheated in a two-stage superheater. The first stage is an electrical heater, and the second stage is a coiled tube heat exchanger inserted in the PDU pulse-combustor exhaust, where the steam receives a final superheat before being piped into the fluidized bed. Typically, the steam plenum is maintained at a temperature in the range of 950 to $1,050{ }^{\circ} \mathrm{F}$. The pulse tubes are fired with natural gas, with combustion air being supplied from an air plenum. To achieve sufficient oscillations at part load, there are provisions for diluting the natural gas with air. Flue gas is sent to the stack.

\section{II.F.2 Combustor Design Qualification Test Facility}

Figure 6 is a block flow diagram for the Combustor Design Qualification Test Facility. Sand, which is fluidized with air from five rental compressors, is used as the fluid bed medium. Water is injected into the bed to impose a heat load on the system and maintain the desired bed temperature. The fluidized-bed off-gas, comprising air used for fluidization and steam generated in the fluid-bed, passes through a cyclone for particulate collection before exiting to the atmosphere. The solids removed in the cyclone are collected in a drum for disposal.

Five fans deliver combustion air to the 253-tube pulse combustor. The combustor is fueled with natural gas, and the flue gas is cooled by a water spray, which is generated by a dual-fluid atomizer using air. The cooled flue gas and steam are vented through a muffler.

The cooling water for the water jacket of the pulse-combustor tubesheets and the aerovalve-plate cooling loop is circulated via a forced circulation pump, with makeup water being provided to cover loses. Steam is vented from the steam drum to maintain the desired operating pressure of approximately $450 \mathrm{psig}$. Figure 7 is a drawing of the gasifier pulse-combustor module. 


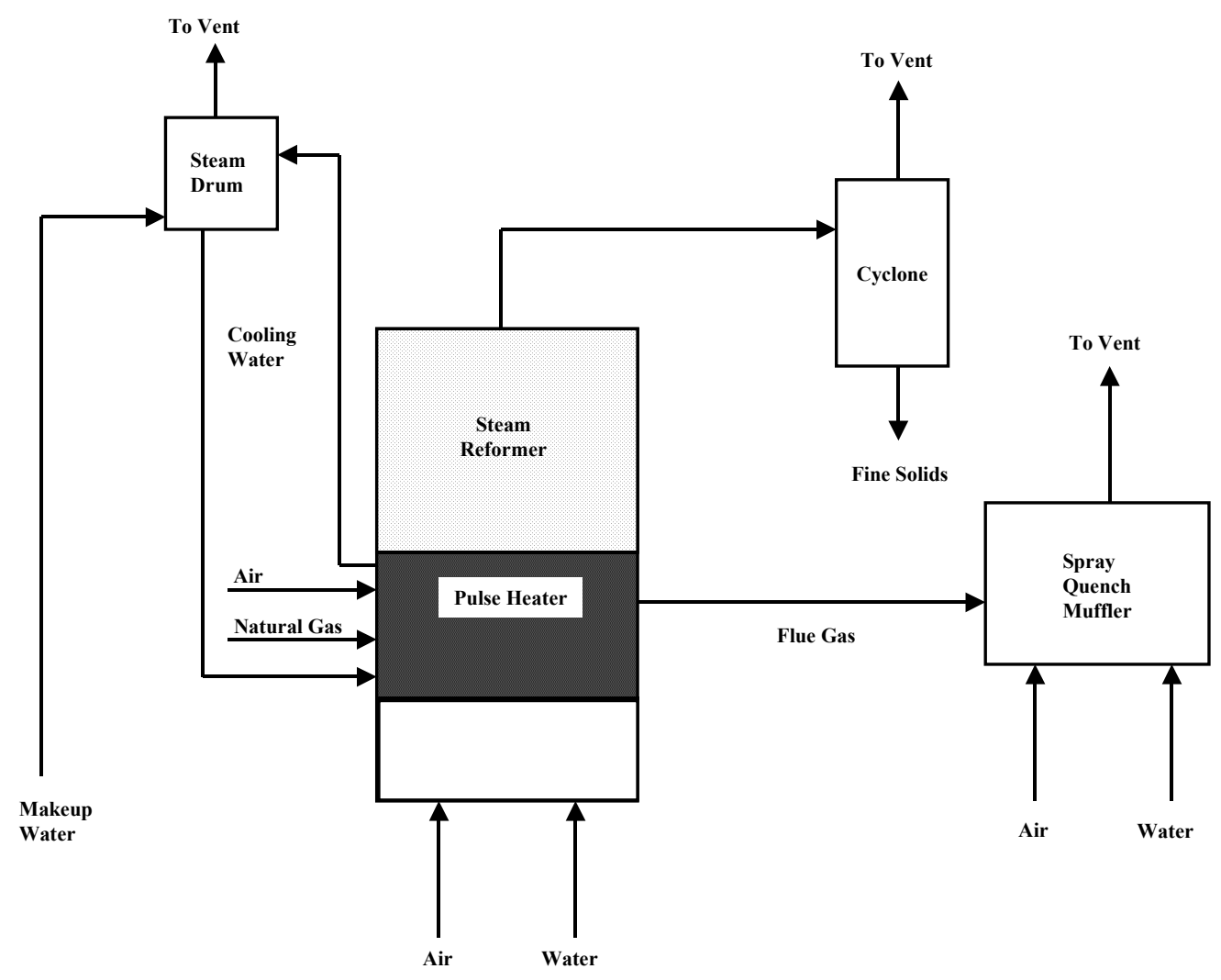

Figure 6. Block Flow Diagram of Combustor Design Qualification Test Facility

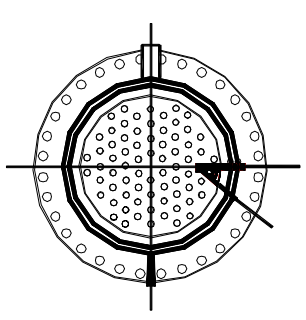

SECTION B

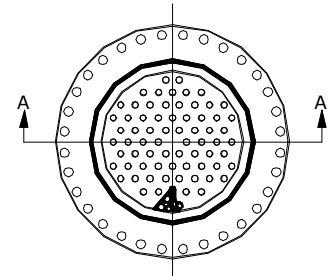

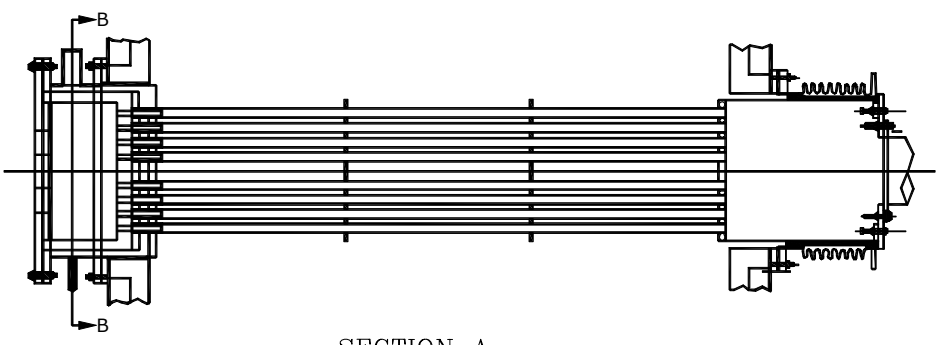

SECTION A

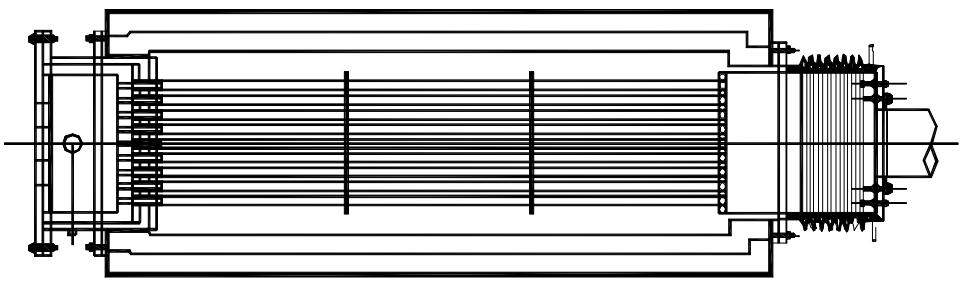

Figure 7. Gasifier Pulse Combustor Module 


\section{II.F.3 Coal Analysis}

The properties of the coal used in the PDU tests are given in Table 1.

Table 1. Coal Analysis

\begin{tabular}{|l|c|}
\hline \multicolumn{2}{|l|}{ Ultimate Analysis, wt\% (dry) } \\
\hline Carbon & 72.00 \\
\hline Hydrogen & 4.87 \\
\hline Nitrogen & 1.08 \\
\hline Sulfur & 0.38 \\
\hline Oxygen & 15.62 \\
\hline Ash & 6.05 \\
\hline Proximate Analysis, wt\% (as received) \\
\hline Fixed Carbon & 37.24 \\
\hline Volatile Matter & 31.76 \\
\hline Ash & 4.44 \\
\hline Moisture & 26.56 \\
\hline $\begin{array}{l}\text { Higher Heating Value, } \\
\text { Btu/lb }\end{array}$ & 8,894 \\
\hline
\end{tabular}

\section{II.G Project Objectives and Statement of Work}

The principal objectives of the reduced-scale version of the project were to perform qualification testing of a 253-tube pulse combustor and to demonstrate readiness of TCI's indirect coal gasification process for commercial deployment. Specific objectives were to

- Demonstrate full-scale pulse-combustor performance, operability, reliability, and availability.

- $\quad$ Demonstrate steam-reformer system performance, operability, reliability, and availability.

- $\quad$ Determine thermal and gasification efficiency with coal feed in the PDU.

- Determine emissions $\left(\mathrm{NO}_{\mathrm{x}}\right.$, sulfur dioxide $\left(\mathrm{SO}_{2}\right)$, total hydrocarbons, and carbon monoxide $(\mathrm{CO}))$.

- Determine regulatory compliance of waste streams from the PDU.

- Determine economic merit of the TCI technology. 
The Statement of Work was broken down into six tasks, as follows, with Task 4 having two subtasks.

$\begin{array}{ll}\text { Task } 1 & \text { Engineering Design } \\ \text { Task } 2 & \text { Fabrication and Installation } \\ \text { Task } 3 & \text { Pulse Combustor System Shakedown and Tuning } \\ \text { Task } 4 & \text { System Qualification Testing } \\ \text { Task } 4.1 & \text { Pulse Combustor Tuning and Performance Verification } \\ \text { Task } 4.2 & \text { Process Data Unit Testing } \\ \text { Task 5 } & \text { Engineering Evaluation } \\ \text { Task } 6 & \text { Management }\end{array}$

This report is mainly concerned with Task 4 , system qualification testing, and only peripherally deals with the other tasks. 


\section{Technical and Environmental Assessment}

\section{III.A Technical Results}

Tests were conducted in two separate facilities to develop data to commercialize pulsecombustor technology. Full-scale heater performance was assessed in the Combustor Design Qualification Test Facility, and coal/steam-reforming process data (product gas yields and composition, char yields and composition, and heat requirements) were determined in the PDU.

\section{III.A.1 Coal/Steam-Reforming Characterization Tests}

The production of char suitable for use as a reductant in DRI guided the selection of the coal to be tested in the PDU. This selection was made in consultation with Northshore Mining. In applications in which char production is a major goal, the primary control variable is operating temperature. The objective of the PDU tests was to identify the lowest temperature at which char with a satisfactory sulfur and volatile matter content, and suitable for use in DRI, could be produced. This temperature should result in the lowest conversion of fixed carbon to gas, thereby increasing char yield. A lower operating temperature also provides a higher tube-to-bed temperature differential, which increases heat transfer into the reformer and increases throughput. Three operating temperatures were evaluated: $1,000,1,100$, and $1,200^{\circ} \mathrm{F}$.

Mass and energy balances were performed for each steady-state PDU test. The coal feed, fluidizing-steam, and instrument-purge (nitrogen) rates were measured for each test. The product gas composition was determined by an on-line GC. Draeger tubes were used to monitor ammonia and hydrogen sulfide in the product gas. An Environmental Protection Agency (EPA) Method 5 gas sampling train was used to collect product gas condensate samples, which were analyzed for volatile organic compounds (VOCs), semivolatile organic compounds (SVOCs), chemical oxygen demand (COD), biological oxygen demand (BOD), chloride, and sulfur and nitrogen compounds. Product char was collected and analyzed. Fluid-bed temperature distribution was monitored by thermocouples inserted in thermowells, and bed height was determined by two sets of pressure-differential measurements.

Product Analyses: Table 2 provides analyses of the char and product gas from the tests at the three temperatures evaluated. It is clear from this table that the ash analyses for the $1,000{ }^{\circ} \mathrm{F}$ and $1,100^{\circ} \mathrm{F}$ runs are in error. Ash analyses for these samples should be lower than for the sample at $1,200^{\circ} \mathrm{F}$, not four to five times higher. The extremely poor ash balances, discussed later, reflect this problem. The incorrect ash analyses impact analyses for other elements in Table 2. 
Table 2. Product Analyses

\begin{tabular}{|l|c|c|c|}
\hline \multirow{2}{*}{ Component } & \multicolumn{3}{|c|}{ Bed Temperature, ${ }^{\mathbf{0}} \mathbf{F}$} \\
\cline { 2 - 4 } & $\mathbf{1 , 0 0 0}$ & $\mathbf{1 , 1 0 0}$ & $\mathbf{1 , 2 0 0}$ \\
\hline Char Analysis, wt\% (dry) & 46.64 & 89.17 \\
\hline Carbon & 55.86 & 0.00 & 0.00 \\
\hline Hydrogen & 0.00 & 0.80 & 1.03 \\
\hline Nitrogen & 0.78 & 0.07 & 0.04 \\
\hline Sulfur & 0.35 & 0.00 & 0.00 \\
\hline Oxygen & 0.00 & 52.49 & 9.76 \\
\hline Ash & 43.01 & 43.98 & 53.93 \\
\hline Gas Analysis, vol\% (nitrogen and water free) & 15.85 & 9.4 \\
\hline Hydrogen & 37.21 & 4.94 & 5.54 \\
\hline Methane & 19.14 & 30.15 & 28.96 \\
\hline Carbon Monoxide & 3.89 & 2.33 & 1.10 \\
\hline Carbon Dioxide & 32.90 & 1.72 & 0.61 \\
\hline Ethylene & 2.64 & 0.22 & 0.13 \\
\hline Ethane & 2.75 & 0.79 & 0.32 \\
\hline Hydrogen Sulfide & 0.32 & 0.00 & 0.00 \\
\hline Propylene & 1.15 & \multicolumn{3}{|c|}{} \\
\hline Propane & 0.00 &
\end{tabular}

Data Analysis: Mass balances were developed for each of the three PDU tests using the measured amounts of coal fed, cyclone product collected, and starting and final bed weights, along with the corresponding chemical analyses. The amount of char in the bed at the end of the test was determined by subtracting the amount of each constituent in the bed at the beginning from that in the bed at the end. The amount of char was added to the amount of cyclone product collected to determine the amount of solid product generated during each test.

The amount of gas produced was determined by nitrogen balance. The amount of nitrogen used as an instrument purge was measured, and the weight of dry product gas was then calculated from the nitrogen content of the product gas as determined by the on-line GC and the quantity of nitrogen fed. The amount of condensate per volume of dry gas was calculated to yield a hydrogen balance. 
The energy balance could not be experimentally determined, because the heat loss from the equipment was much greater than the process-heat load. This is not a significant problem, since the heat of reaction can be calculated from the known heats of combustion of the products and reactants.

Elemental closures (see Table 3) were about as expected, considering the size of the equipment. The ash closure was off more than other constituents because small differences were determined within large numbers (the bed of sand weighs more than all the ash fed during the tests). Nitrogen and hydrogen closures were forced by the calculation procedure. Overall material balances (out/in) varied from 1.093 to 1.135. Although typical of data from units of this scale, these data are not accurate enough to permit design of a full-scale unit.

Table 3. Mass Balances

\begin{tabular}{|l|c|c|c|}
\hline \multirow{2}{*}{$\begin{array}{l}\text { Mass Balance } \\
\text { Closure, out/in }\end{array}$} & $\mathbf{1 , 0 0 0}$ & $\mathbf{1 , 1 0 0}$ & $\mathbf{1 , 2 0 0}$ \\
\cline { 2 - 4 } & 0.859 & 0.732 & 1.364 \\
\hline Carbon & 1.000 & 1.000 & 1.000 \\
\hline Hydrogen $^{\mathrm{a}}$ & 1.000 & 1.000 & 1.000 \\
\hline Nitrogen $^{\mathrm{a}}$ & 1.262 & 0.547 & 1.071 \\
\hline Sulfur & 1.151 & 1.123 & 1.016 \\
\hline Oxygen $^{\mathbf{0}} \mathbf{F}$ & 0.819 \\
\hline Ash & 5.663 & 6.739 & 1.093 \\
\hline Total & 1.135 & 1.116 & \\
\hline
\end{tabular}

${ }^{\mathrm{a}}$ Hydrogen and nitrogen balances were forced by the calculation procedure.

Table 4 presents the VOCs and SVOCs collected in the condensate. Since full-scale, commercial, cold-gas-cleanup equipment does not achieve ice-bath temperature and since the commercial steam reformer will have reduced freeboard (disengaging space) heat losses and higher gas residence times, these captured organic-condensate quantities should represent an upper limit.

The amount of carbon and sulfur in the char decreases with increasing temperature. The condensate contains a lower fraction of carbon as temperature increases. In order to maximize char production, operation at 1,000 to $1,100^{\circ} \mathrm{F}$ would be preferred. Char suitable for DRI is generated in this temperature range. 
Table 4. SVOC and VOC Analyses

\begin{tabular}{|l|c|r|r|}
\hline \multirow{2}{*}{ Compound } & \multicolumn{3}{|c|}{ Bed Temperature, ${ }^{\mathbf{0}} \mathbf{F}$} \\
\cline { 2 - 4 } & $\mathbf{1 , 0 0 0}$ & $\mathbf{1 , 1 0 0}$ & $\mathbf{1 , 2 0 0}$ \\
\hline Semivolatile Organic Compounds, $\mathbf{~ m g / k g}$ of dry feed \\
\hline Phenols & 1860.2 & 1111.2 & 276.3 \\
\hline Naphthalene & 1.4 & 0.7 & 0.3 \\
\hline Aniline & 6.4 & 3.7 & 1.1 \\
\hline Other SVOCs & 0.3 & 1.9 & 0.6 \\
\hline \multicolumn{1}{|c|}{ Total SVOCs } & $\mathbf{1 8 6 8 . 3}$ & $\mathbf{1 1 1 7 . 5}$ & $\mathbf{2 7 8 . 3}$ \\
\hline Volatile Organic Compounds, $\mathbf{~ m g / k g ~ o f ~ d r y ~ f e e d ~}$ & & \\
\hline Acetone & 434.1 & 104.8 & 39.1 \\
\hline 2-Butanone & 124.0 & 57.7 & 8.5 \\
\hline Benzene & 15.9 & 11.0 & 2.3 \\
\hline Toluene & 12.4 & 6.8 & 1.4 \\
\hline Xylenes & 4.3 & 2.1 & 0.4 \\
\hline Styrene & 1.8 & 0.8 & 0.2 \\
\hline Naphthalene & 1.2 & 0.0 & 0.3 \\
\hline \multicolumn{1}{|c|}{ Total VOCs } & $\mathbf{5 9 3 . 7}$ & $\mathbf{1 8 3 . 2}$ & $\mathbf{5 2 . 2}$ \\
\hline
\end{tabular}

\section{III.A.2 Combustor Qualification Tests}

Performance characteristics of a full-scale, multiple-resonance-tube, pulse combustor were determined in the test facility constructed as part of this project. The combustor was fired on natural gas for most of the testing program. The pulse combustor's role in the coal/steamreforming process is to provide the required process heat. The amount of heat supplied by the pulse combustor was determined at several firing rates and excess-air levels, which were the main variables examined. (Table 5 presents the test matrix.) The heat-transfer rate to the fluidized bed is dependent upon conditions in the bed and the tube-to-bed temperature difference. Tube and bed temperatures were monitored and used in conjunction with energybalance data to determine the heat transferred to the fluidized bed. Combustor efficiency and emissions $\left(\mathrm{SO}_{2}, \mathrm{NO}_{\mathrm{x}}\right.$, total hydrocarbons, and $\left.\mathrm{CO}\right)$ were determined at various firing rates, excess-air levels, recycle-flue-gas rates, and fluidized-bed operating temperatures. 
Table 5. Combustor Qualification Test Matrix

\begin{tabular}{|l|c|}
\hline Variable & Value or Range \\
\hline Number of Test Series & 6 \\
\hline Firing Rate, MBtu/h & 4 to 23 \\
\hline Flue-gas Recycle & No and Yes \\
\hline Inner Shield Tube & Long-26 in. long; Short-5 in. long \\
\hline Fuel & Natural Gas; $\mathrm{H}_{2}$ Rich Syngas \\
\hline Fluidized Bed Temperature, ${ }^{\circ} \mathrm{F}$ & 50 to 1,350 \\
\hline Water Bath Temperature, ${ }^{\circ} \mathrm{F}$ & 212 \\
\hline
\end{tabular}

The Combustor Design Qualification Test Facility was filled with sand and fluidized with air. Water was injected into the bed to impose a heat load and control bed temperature independently of the combustor firing rate. Gas and combustion-air flow rates were measured for each test. Fluidized-bed temperature, fluidizing air flow, water flow for bed temperature control, pulsecombustor exhaust temperature, resonance-tube temperatures, combustion-air temperature, and combustor-cooling-circuit steam generation were measured for each test, allowing calculation of an energy balance, heat transferred to the bed, and the tube-to-bed heat-transfer coefficient.

Data Analysis: A total of six test series were conducted for the Qualification Test. The different configurations and conditions tested are listed in Table 6. Data were obtained for both the up and down ramping of the pulse-combustor firing rate. Test Series 1 was made to shake down the system. Results from Test Series 2 and 3, which are most applicable to low-temperature char production, are presented in Table 7. Raw data for Series 4, 5, and 6 were provided in the Final Report (ThermoChem 2002b), but these data were not worked up, and reduced data results for these run series were not provided.

Table 6. Qualification Test Configurations

\begin{tabular}{|l|c|c|c|c|c|c|}
\hline $\begin{array}{c}\text { Test } \\
\text { Series }\end{array}$ & $\begin{array}{c}\text { Bed Temp., } \\
{ }^{\mathbf{0}} \mathbf{F}\end{array}$ & $\begin{array}{c}\text { Water } \\
\text { Bath } \\
\text { Temp., }\end{array}$ & $\begin{array}{c}\text { F } F \\
\text { Firing } \\
\text { Rate, } \mathbf{1 0}^{\mathbf{6}} \\
\text { Btu/h }\end{array}$ & Fuel $^{\text {a }}$ & $\begin{array}{c}\text { Flue-gas } \\
\text { Recycle }\end{array}$ & $\begin{array}{c}\text { Shield Tube } \\
\text { Length, in. }\end{array}$ \\
\hline $1^{\text {b }}$ & Up to 1,100 & ----- & up to 14 & NG & No & 24 \\
\hline $2^{\text {b }}$ & Up to 1,100 & ----- & up to 22 & NG & Yes \& No & 24 \\
\hline $3^{\text {b }}$ & Up to 1,200 & ----- & up to 22 & NG & Yes \& No & 24 \\
\hline $4^{\text {b }}$ & Up to 1,350 & ----- & up to 23 & NG & Yes \& No & 3 \\
\hline 5 & ----- & 212 & up to 16 & NG & No & 3 \\
\hline 6 & ----- & 212 & up to 11 & Syngas & No & 3 \\
\hline
\end{tabular}

${ }^{\mathrm{a}} \mathrm{NG}=$ Natural gas; ${ }^{\mathrm{b}}$ Air fluidized bed

The natural-gas firing rate was ramped up to about $21 \mathrm{MBtu} / \mathrm{h}$ and held steady for about 
$10 \mathrm{~h}$. The pulse combustor operated well with strong pulsations and air suction with selfaspiration increasing significantly with firing rate. The dynamic pressure in the combustion chamber was monitored during the test through an HP spectrum analyzer. The pulsation frequency was generally on the order of $58 \mathrm{~Hz}$. The sound pressure level varied from $165 \mathrm{~dB}$ ( $\sim 1.5$ psi peak-to-peak pressure fluctuation) at $\sim 6 \mathrm{MBtu} / \mathrm{h}$ firing rate to about $173 \mathrm{~dB}(\sim 4 \mathrm{psi}$ peak-to-peak pressure fluctuation) at $\sim 20 \mathrm{MBtu} / \mathrm{h}$ firing rate. Because of self-aspiration, the demand on static pressure in the air plenum of the pulse combustor is rather low, less than 12 in. $\mathrm{H}_{2} \mathrm{O}$ at a $21 \mathrm{MBtu} / \mathrm{h}$ firing rate.

The thermal response of the bed to pulsed heating is quite rapid with bed heatup rates in the range 50 to $200^{\circ} \mathrm{F} / \mathrm{h}$. The nominal bed temperature during the run was $1,000^{\circ} \mathrm{F}$, with peak temperature reaching $1,100^{\circ} \mathrm{F}$. Water injection into the bed was started above $1,050^{\circ} \mathrm{F}$ to regulate the bed temperature. The pulse-combustion-chamber temperature averaged about $2,400^{\circ} \mathrm{F}$.

The composition of the flue gas from the combustor was monitored by a continuous emissions monitoring system, calibrated and operated by personnel from TRC Environmental Corporation of Connecticut. The oxygen concentration was in the 4- to10-percent range during stable firing of the combustor, corresponding to between 20- and 80-percent excess air. When there was no flue-gas recycle, the oxygen concentration was relatively high. The high excess-air operation was necessary to modulate combustion chamber temperature, and $\mathrm{NO}_{\mathrm{x}}$ emissions were relatively high because of the high oxygen concentration. With flue-gas recycle, the oxygen and $\mathrm{NO}_{\mathrm{x}}$ levels were reduced significantly. $\mathrm{NO}_{\mathrm{x}}$ concentrations were in the 10 to 30 parts per million by volume (ppmv) range.

$\mathrm{CO}$ concentration ranged from 100 to $400 \mathrm{ppmv}$ during stable firing. Flow and temperature profiles had to be established and stabilized to achieve complete combustion. Total hydrocarbons (THC) emissions were generally low ( $<20$ ppmv) except during transients, indicating high combustion efficiency. Carbon dioxide concentration ranged from 7 to 10 percent during stable firing. Table 7 shows that, with only two exceptions, combustion efficiency was in the range of 99.6 to100 percent, independent of firing rate, excess air, or fluidized-bed temperature. 
Table 7. Combustor Qualification Test Results for Series 2 and 3

\begin{tabular}{|c|c|c|c|c|c|c|c|}
\hline Test No. & $\begin{array}{c}\text { Comb. } \\
\text { Chamber } \\
\text { Temp., }{ }^{\circ} \mathbf{F}\end{array}$ & $\begin{array}{l}\text { Decoupler } \\
\text { Temp., }{ }^{\circ} \mathrm{F}\end{array}$ & $\begin{array}{c}\text { Bed } \\
\text { Temp., } \\
{ }^{\circ} \mathbf{F}\end{array}$ & $\begin{array}{c}\text { Firing Rate, } \\
10^{6} \mathrm{Btu} / \mathrm{h}\end{array}$ & $\begin{array}{c}\text { Heat } \\
\text { Transferred, } \\
\%\end{array}$ & $\begin{array}{c}\text { Combustion } \\
\text { Eff., } \%\end{array}$ & 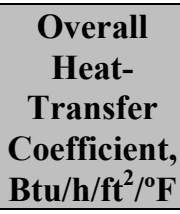 \\
\hline $2-1^{a}$ & 2476 & 1236 & 983 & 17.29 & 54.5 & 99.70 & 13.6 \\
\hline $2-2^{a}$ & 2426 & 1250 & 835 & 20.61 & 56.6 & 99.62 & 13.4 \\
\hline $2-3^{a, b}$ & 2445 & 1187 & 863 & 20.49 & 46.6 & 99.85 & 12.1 \\
\hline $2-4$ & 2691 & 1232 & 932 & 17.50 & 45.9 & 99.98 & 9.8 \\
\hline $3-1$ & 1925 & 1045 & 747 & 8.93 & 55.3 & 99.10 & 7.8 \\
\hline $3-2$ & 2101 & 1154 & 822 & 11.79 & 54.2 & 99.88 & 9.2 \\
\hline $3-3$ & 2454 & 1246 & 893 & 3.88 & 54.8 & 99.95 & 9.4 \\
\hline $3-4$ & 2441 & 1246 & 888 & 18.10 & 53.8 & 99.86 & 12.0 \\
\hline $3-5$ & 2483 & 1234 & 916 & 19.90 & 54.0 & 99.79 & 13.8 \\
\hline $3-6$ & 2487 & 1152 & 890 & 13.69 & 46.7 & 99.97 & 8.7 \\
\hline $3-7^{b}$ & 2448 & 1279 & 959 & 21.20 & 48.8 & 99.93 & 13.7 \\
\hline $3-8^{b}$ & 2494 & 1228 & 932 & 19.24 & 49.0 & 99.93 & 12.5 \\
\hline $3-9^{b}$ & 2489 & 1226 & 962 & 17.77 & 50.1 & 99.88 & 12.5 \\
\hline $3-10^{b}$ & 2202 & 1241 & 1012 & 14.44 & 49.3 & 99.91 & 12.3 \\
\hline $3-11^{b}$ & 2266 & 1247 & 1065 & 12.37 & 50.5 & 99.93 & 11.6 \\
\hline $3-12^{b}$ & 2346 & 1217 & 1060 & 9.87 & 49.7 & 99.95 & 9.2 \\
\hline $3-13$ & 1494 & 644 & 608 & 3.30 & 37.1 & 98.57 & 4.6 \\
\hline $3-14$ & 2032 & 733 & 635 & 5.04 & 31.5 & 99.92 & 3.3 \\
\hline $3-15$ & 2229 & 856 & 715 & 5.99 & 36.6 & 99.97 & 3.8 \\
\hline $3-16$ & 2552 & 1256 & 997 & 17.61 & 49.8 & 99.97 & 12.2 \\
\hline 3-17 & 2545 & 1356 & 1063 & 20.88 & 55.3 & 99.94 & 15.8 \\
\hline $3-18$ & 2432 & 1260 & 1017 & 14.98 & 54.1 & 99.89 & 12.3 \\
\hline $3-19^{a}$ & 2537 & 1275 & 987 & 17.58 & 53.7 & 99.87 & 12.7 \\
\hline
\end{tabular}

${ }^{\mathrm{a}}$ Fuel dilution with air

${ }^{\mathrm{b}}$ Flue-gas recycle

${ }^{\mathrm{c}}$ Heat-transfer coefficients were not provided in the Final Report. The values shown were calculated from other data provided in the Final Report.

Figure 8 shows the percent of the heat released that is transferred to the fluidized bed and the water jacket as a function of firing rate. This percent remains relatively constant at a little over 50 percent except at low firing rates (less than about $7 \mathrm{MBtu} / \mathrm{h}$ ). 


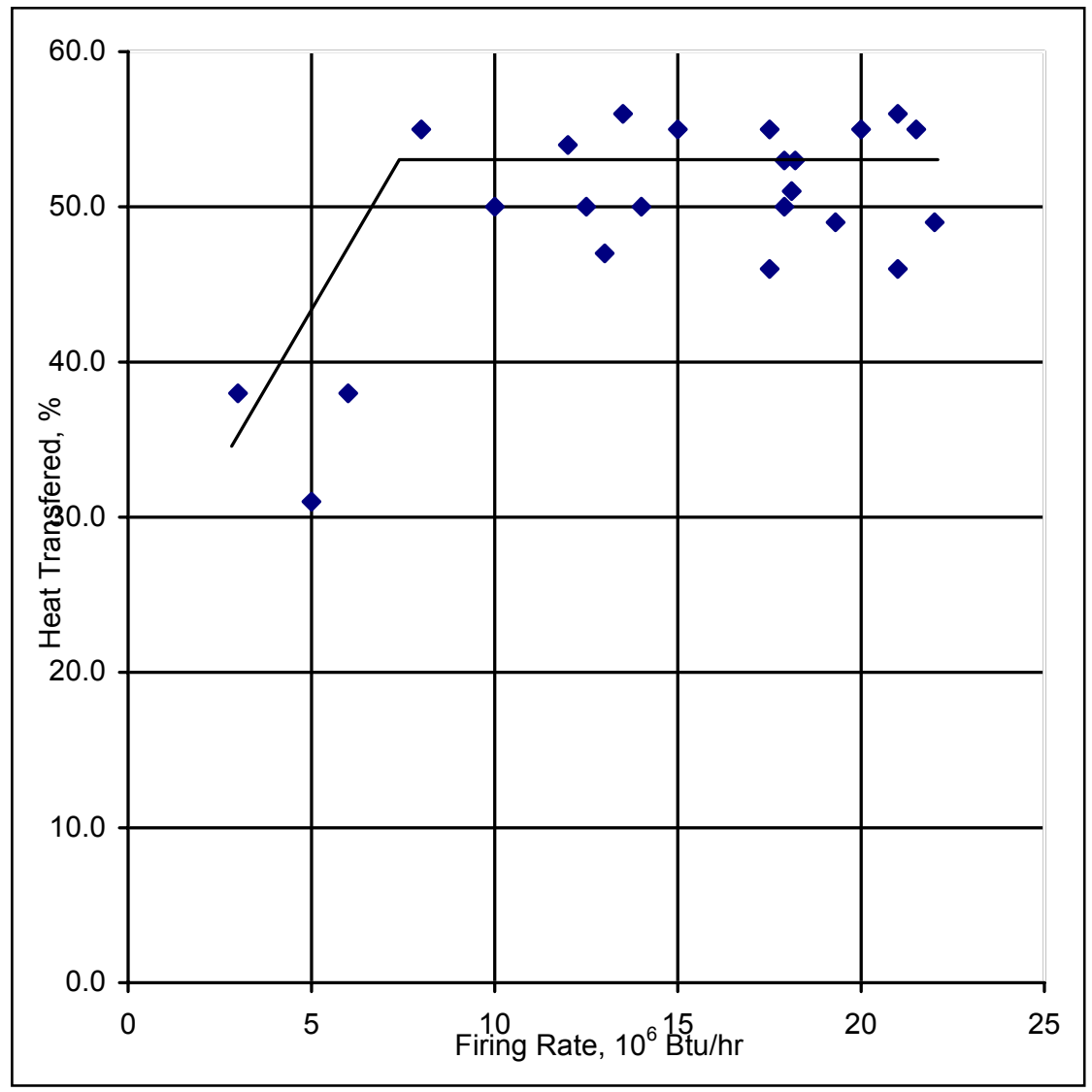

Figure 8. Fraction of Heat Transferred as a Function of Firing Rate

\section{III.A.3 Evaluation of Test Results}

It is difficult to evaluate the significance of these test results. The Final Report (ThermoChem 2002b) provides reduced data only for Test Series 2 and 3, the conditions determined by TCI to be most applicable to char production for DRI. (Although this report states that heat-transfer coefficients were calculated, no heat-transfer coefficients are presented in the report.)

To get a feel for the improvement in heat transfer resulting from pulse combustion, overall heattransfer coefficients were calculated based on the data presented. (See last column in Table 7.) In an earlier analysis (Turdera and Zahradnik 1992), K \& M Engineering and Consulting Corporation calculated heat-transfer coefficients based on data from tests made by ThermoChem on a 61-tube prototype pulse combustor. $\mathrm{K} \& \mathrm{M}$ calculated overall heat-transfer coefficients in the range of 6.3 to 11.3 , in overall agreement with the values presented in Table 7. $\mathrm{K} \& \mathrm{M}$ also calculated tube heat-transfer coefficients and found these to be about twice the theoretical values for non-pulsed tubes. Based on K \& M's analysis and the data reported by ThermoChem, it appears that the heat-transfer coefficient inside a pulsed tube may be 2 to 2.5 times higher than for a non-pulsed tube. 
Many of the stated advantages of the pulse combustor (Durai-Swamy et al. 1994) only apply to the combustion of solid fuels and are not applicable to combustion of gaseous fuels, which is the intended fuel for operations to produce char for DRI. Fuel gas does not have the diffusion problem characteristic of coal combustion and burns much more rapidly. Also, as has been previously stated, the tests on the full-scale combustor were carried out in a sand bed, quenched with water to maintain temperature control. This is a considerably different and much cleaner environment than would exist if the bed consisted of coal and char particles. Thus, no information was gathered on the tendency of the 253-tube bundle to foul or the effect fouling would have on the heat-transfer coefficient. However, TCI has indicated that they did not observe fouling in tests on black liquor from the pulp and paper industry and believe that this indicates that fouling will not occur with coal. They also indicate that no fouling was observed in the two-tube PDU (Rockvam 2002).

In summary, although the indirectly heated steam/coal gasifier may have specific uses, it is not possible based on the limited tests conducted in this project, to clearly determine the advantage of this technology. Further testing is needed to evaluate pulse-combustor applications.

\section{III.B Environmental Performance}

The principal objective of this scaled-down project was to perform qualification testing of a 253-tube pulse combustor to determine its readiness for commercial deployment. Assessing the potential environmental benefits that any new technology could have upon deployment requires consideration of a broad range of parameters, including air and water emissions, hazardous material issues, solid wastes generated, federal environmental regulations, state permitting requirements, and local regulations.

The original purpose of this CCT project was to demonstrate a full-size unit having ten identical pulse-tube combustors. Figure 9 depicts a ten-unit, 300 tons/day gasifier installation. However, the scaled-down CCT project only tested a single 253-resonance-tube combustor. Therefore, some scaleup issues need to be considered prior to replicating the technology at full scale. 


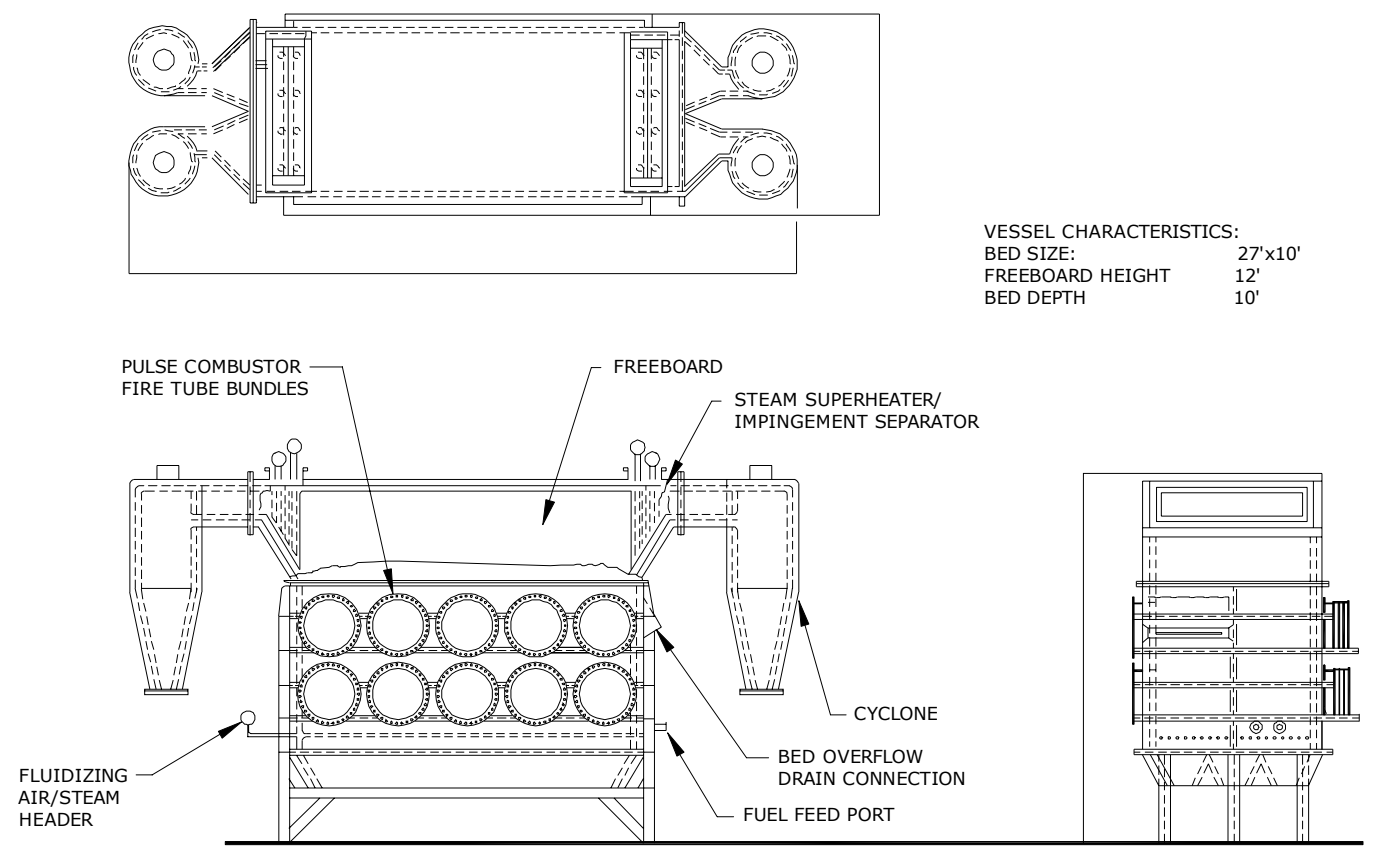

Figure 9. Schematic Drawing of 300 Tons/Day Gasifier

Although there were no environmental impacts associated with this project because of its small scale, several potential problem areas for this technology need to be addressed. Potential concerns include the volume and nature of the solid and liquid wastes produced, air emissions stemming from the process, and noise pollution. In these areas, additional information may need to be generated to more fully assess the technology.

Noise: Noise, often governed by local ordinances, could be an important issue when replicating this technology. Ambient noise levels, especially for projects where noise will be a continuing issue, must be estimated. The scaled-up version of the pulse combustor, with multiple 253-tube bundles, could emit a substantial amount of noise, if fired without appropriate noise abatement measures. If decibel levels are above Occupational Safety and Health Administration (OSHA) or community standards, effective noise mitigation measures will have to be implemented. ThermoChem has indicated that the MTCI/TCI design incorporates acoustic muffling measures in the air-inlet plenum and the exhaust decoupler. Also being considered is a tandem arrangement, or pairing, of two combustors to run 180 degrees out of phase to cancel out noise emissions. According to ThermoChem, designs for commercial applications have a target for noise emissions of less than $85 \mathrm{~dB}$ at 3 feet (Rockvam 2003).

Although measurements were made during this project, estimated noise levels at a full-scale pulse-combustor facility as well as potential impacts on ambient noise levels for the surrounding community and on-site workers were not discussed in ThermoChem's final report. An analysis of noise levels and noise reduction methods should be conducted prior to replication of the pulse 
combustor. To facilitate compliance with OSHA noise-level requirements, a noise-control plan, which provides reduction measures for a full-scale pulse-combustor facility to mitigate the negative impacts on workers, should be implemented.

Wastewater: Process condensate is the only wastewater stream generated in this process. Biological oxygen demand (BOD) is one of the concerns with this effluent. (BOD as a function of operating temperature is presented in Table 8.) The fact that there is little difference in char and gas yields between the lower two operating temperatures explains why there is little difference in effluent quality for these operating conditions. At the higher temperature, gasification increases, and some of the liquid organics that contribute to BOD are destroyed.

Table 8. Effluent BOD Analyses

\begin{tabular}{|l|r|r|r|}
\hline Temperature & $\mathbf{1 , 0 0 0}^{\circ} \mathbf{F}$ & $\mathbf{1 , 1 0 0}^{\circ} \mathbf{F}$ & $\mathbf{1 , 2 0 0}^{\circ} \mathbf{F}$ \\
\hline BOD, lb/ton dry coal & 13.98 & 15.27 & 3.04 \\
\hline BOD, lb/ton dry char & 19.30 & 22.09 & 6.55 \\
\hline
\end{tabular}

A facility producing 20 tons of char per hour and operating at $1,000^{\circ} \mathrm{F}$ would produce a raw effluent stream containing approximately 5 tons/day of BOD. Although this raw effluent could not be discharged directly into a stream, conventional aerobic digestion technology would provide adequate treatment to address the BOD problem. A treatment facility would be required even for the higher temperature operating condition. However, a zero-discharge approach would be desirable in today's more stringent regulatory environment. Therefore, methods to recover and recycle or use these aqueous constituents should be devised and implemented at any scaledup facility. Additional investigation into the adequacy of conventional aerobic digestion for complete removal of harmful constituents would be needed to assure that this discharge is environmentally acceptable.

Solid Waste: The technology produces char, tars, and fuel gas when operating for the mild gasification of coal. The intended use for the char is as a reductant in the steel industry (ThermoChem 2002b). Although the nature, volume, and chemical constituents of the tar produced in the process were measured, this material would have to be further quantified and characterized prior to replication of the technology. This would ensure that this waste stream was non-hazardous and that adequate disposal procedures could be devised.

Air Emissions: The 253-bundle pulse combustor in this study was fired by natural gas. However, a typical full-scale unit using ten pulse-tube combustors would likely be designed to fire syngas produced by the process. Although some runs are reported as being made on (synthetic) syngas, air emissions during firing syngas were not reported. It is likely that the syngas used did not contain the contaminants expected in coal-derived syngas. 


\section{Market Analysis}

\section{IV.A Market Size/Commercialization}

The initial concept for this technology was to produce char for use as a DRI reductant. However, in addition to this use, ThermoChem has proposed several other potential market applications, including

- Black-liquor processing and chemical recovery;

- Hazardous, low-level mixed waste volume reduction and destruction;

- Coal processing for production of

- $\quad$ hydrogen for fuel cell power generation and other uses,

- $\quad$ gas and char for the steel industry,

- $\quad$ solid Clean Air Act compliance fuels, and

- $\quad$ syngas for use as a fuel or as a feedstock for chemicals or high-quality liquid-fuels production;

- Coal-pond waste and coal rejects processing for overfiring/reburning for utility $\mathrm{NO}_{\mathrm{x}}$ control; and

- Utilization of a range of other fuels and wastes to produce a variety of value added products.

Recognizing that the CCT Demonstration Program is intended to expand the market for coal and improve the competitiveness of coal domestically, especially in the electric power market, a preliminary assessment of the most promising coal applications of the MTCI technology was conducted. These applications considered mild gasification of coal (using the MTCI technology) to produce (1) metallurgical coke replacement, (2) compliance coal for existing power plants, and (3) syngas for use as an industrial feedstock and for power production.

\section{IV.A.1 Market Size}

Because this technology is in an early stage of development and only limited data is available, it is difficult to judge the market for the potential applications listed above. The Final Report (ThermoChem 2002b) provides data on only one coal, which was already low sulfur $(0.38$ percent). Data on a variety of other coals, particularly higher-sulfur coals, are needed to enable an adequate assessment of possible technology applications. Another problem is that the coal/steam reforming was only performed in the PDU. The commercial-scale pulse-tube combustor only operated in a sand bath. Therefore, we do not know whether or not the pulse tubes would foul when exposed to coal or other problems would arise. 
Thus, the following analyses of potential markets should be considered as preliminary. Furthermore, for applications where the main product is syngas, either a concurrent market for char needs to exist, or else complete coal gasification needs to occur. Complete gasification has not been demonstrated, so considerable additional development work is required before opportunities to supply syngas can be seriously considered. A potential market for the destruction of hazardous wastes is also questionable, since such wastes generally require very high levels of destruction, and such high conversion levels are difficult to achieve at the reported gasifier temperatures. That the TCI technology can accomplish this would have to be demonstrated, although TCI asserts that it has data from another project bearing on this issue (ThermoChem 1998), but this data was not included in the Final Report (ThermoChem 2002b).

Metallurgical-Coke Replacement: Integrated metallurgical-coke production in 1996 was approximately 18.5 million short tons. Although blast-furnace metallurgical-coke consumption has declined by almost 1.8 million short tons since then to 16.7 million tons, there remains a shortage of coke of over 4 million tons from integrated mills. As a result of the planned closing of several coke plants, the shortfall rose by 265,000 tons in 1998 and an additional 900,000 tons in 1999. This brings the total shortfall to over 5 million tons, which is expected to be met by domestic merchant coke plants.

The U.S. steel industry is currently in an economic downswing. This is probably the single most dramatic barrier to be overcome by the DRI and coking applications. Natural gas pricing will also have a major impact on incentives to proceed with steam-reforming projects.

Compliance Coal: The acid-rain provisions (Title IV) of the Clean Air Act Amendments of 1990 required existing coal-fired power plants to reduce their $\mathrm{SO}_{2}$ emissions. To comply with this requirement, many power plants switched to coal (known as "compliance coal") with a sulfur content that met the emissions target. Coal switching is a popular compliance strategy because of its relatively low cost, since it avoids the capital investment required for flue-gas desulfurization (FGD) or other $\mathrm{SO}_{2}$ control technology.

During the steam-reforming process, much of the sulfur in the coal is removed as hydrogen sulfide, with the result that the char produced is much lower in sulfur than the feed coal. Thus, there is potential for this technology to convert higher sulfur coals into a compliance fuel that could find a market at a number of power plants.

Synthesis Gas for Power Production: Synthesis gas can be used instead of natural gas or oil in combustion turbines to produce electric power. Three CCT demonstration projects were designed to demonstrate the conversion of coal to electric power through syngas production as an intermediate step. The MTCI technology can also produce synthesis gas from coal, which can be burned in combustion turbines to produce electric power. At present, over 95,000 megawatts (MWe) of electric power is produced by combustion turbines, either stand-alone or in a combined cycle, fueled by natural gas. These units generate over 80 billion kilowatt hours (kWh) annually and consume almost 3 trillion cubic feet of natural gas.

Natural gas is currently the preferred fuel for new electric generating capacity. This is because 
(1) current fuel prices, which comprise about 90 percent of the operational costs for a natural gas combined cycle (NGCC) facility, are relatively low; (2) the capital cost of combined-cycle plants is low, and the time to install them is relatively short; (3) the efficiency of combined cycle plants is high and improving; and (4) the environmental issues associated with gas use are fewer than with most of the economically viable alternatives. If it can be produced cheaply enough, syngas can replace natural gas in this application.

Synthesis Gas for Use as a Feedstock: Conventional methods for reforming natural gas to synthesis gas are capital intensive. As a result, the cost of synthesis gas derived from natural gas is roughly 1.5 to 3 times the price of the natural gas feedstock. At a natural gas price of $\$ 3$ to $\$ 4 /$ MBtu, the cost of synthesis gas is on the order of $\$ 4.50$ to $\$ 12 / \mathrm{MBtu}$. At locations where a commercial-scale MTCI steam reformer can produce a syngas having comparable chemical properties within or below this price range, there may be market opportunities for the technology.

The cost of syngas produced by the MTCI technology depends upon the price of the coal used as feedstock. To compete with $\$ 4.50 / \mathrm{MBtu}$ conventional syngas, a large MTCI plant would have to use $\$ 23$ to $\$ 25 /$ ton coal. A small MTCI plant would have to use $\$ 5 /$ ton coal and a 15 -percent internal rate of return (IRR) to be competitive with $\$ 4.50$ syngas. At the upper end of the conventional syngas cost range, the MTCI technology should be competitive no matter what the coal price or the IRR.

\section{IV.A.2 Commercialization Plan}

Current plans are to work with a recognized company, such as Midrex, that has extensive experience and contacts within the steel and related industries. ThermoChem is currently in contact with Midrex discussing areas of mutual interest. Midrex's technical in-house capabilities would provide the innovative MTCI steam-reforming process with valuable design and operating experience for construction and operation of the first plant.

\section{IV.B Economics}

\section{IV.B.1 Capital Costs}

Capital-cost estimates are only preliminary in nature, because of lack of data from a full-scale unit. The cost shown in Table 9 is for the commercial mild gasification of sub-bituminous coal to provide char for the Northshore Mining Company. The projections were made based on a budget-estimate study performed by Industra, completed in July 1997, which was adjusted for inflation and other considerations; scaleup from similar systems for spent liquor recovery have provided new cost data since July 17, 1997 (ThermoChem 2002a).

The plant is based on a reactor with five 253-tube pulse combustors having a nominal coal processing (mild gasification) capacity of 40 tons/h. For the purpose of operating cost calculations, the plant was assumed to be operating at 36 tons/h ( 90 percent on stream factor). Coal is fed into the steam reformer utilizing a weigh feeder and a water-cooled injection screw 
feeder. Ash and unreacted char are removed from the reformer by lockhoppers and a cooling conveyor. A cold-gas cleanup train is used to process the raw gas from the steam reformer. Cyclones provide initial particulate control, followed by a venturi scrubber to remove any remaining entrained particulates. A gas cooler with acidic $\mathrm{pH}$ control provides the dual purpose of cooling the gas (condensing the steam) and ammonia removal. The hydrogen sulfide absorber contacts the relatively cool gas $\left(125^{\circ} \mathrm{F}\right)$ with a caustic to remove the sulfur as a sodium bisulfide solution. The sulfide solution will be sold to a local pulp mill as chemical makeup for the pulping process. The final syngas is clean and acceptable for burning as a fuel in the pulse combustor, as well as in boilers for steam generation. Table 9 presents the total installed cost, major equipment costs, and other costs associated with field erection of the plant.

Table 9. Projected Total Installed Cost

\begin{tabular}{|c|c|c|c|}
\hline \multirow[t]{2}{*}{ Item Description } & \multicolumn{2}{|l|}{ Unit Cost } & \multirow[t]{2}{*}{ Item Total Cost } \\
\hline & $\begin{array}{l}\text { Equipment/ } \\
\text { Material }\end{array}$ & $\begin{array}{l}\text { Installation/ } \\
\text { Subcontract }\end{array}$ & \\
\hline \multicolumn{4}{|l|}{ Direct Costs: } \\
\hline Major Equipment & $\$ 5,440,000$ & $\$ 756,000$ & $\$ 6,196,000$ \\
\hline Piping & $\$ 1,170,000$ & $\$ 1,013,000$ & $\$ 2,183,000$ \\
\hline Electrical & $\$ 170,000$ & $\$ 250,000$ & $\$ 420,000$ \\
\hline Instrumentation \& Control & $\$ 670,000$ & $\$ 530,000$ & $\$ 1,200,000$ \\
\hline Site Preparation & $\$ 20,000$ & $\$ 130,000$ & $\$ 150,000$ \\
\hline Civil/Structure & $\$ 25,000$ & $\$ 100,000$ & $\$ 125,000$ \\
\hline \multirow[t]{2}{*}{ Building } & $\$ 600,000$ & $\$ 660,000$ & $\$ 1,260,000$ \\
\hline & $\$ 8,095,000$ & $\$ 3,439,000$ & \\
\hline Operation \& Startup Spares & & & $\$ 700,000$ \\
\hline $10 \%$ Escalation & & & $\$ 1,250,000$ \\
\hline Land & & & $\$ 500,000$ \\
\hline Preliminary Expenses/Project Fees & & & $\$ 2,250,000$ \\
\hline Insurance and Permits & & & $\$ 2,100,000$ \\
\hline Warranty \& Licensing Fees & & & $\$ 1,800,000$ \\
\hline $10 \%$ Execution Contingency & & & $\$ 1,950,000$ \\
\hline Direct Cost Total & & & $\$ 22,084,000$ \\
\hline \multicolumn{4}{|l|}{ Indirect Costs: } \\
\hline Detailed Engineering & & & $\$ 1,500,000$ \\
\hline Project \& Construction Management & & & $\$ 1,700,000$ \\
\hline Commissioning and Startup & & & $\$ 650,000$ \\
\hline General \& Administrative Expenses & & & $\$ 1,500.000$ \\
\hline General Contingency & & & $\$ 750,000$ \\
\hline Indirect Cost Total & & & $\$ 6,100,000$ \\
\hline Project Total Installed Cost & & & $\$ 28,184,000$ \\
\hline
\end{tabular}

\section{IV.B.2 Operating Costs}

Estimated operating costs are presented in the Public Design Report (ThermoChem 2002a). Some adjustments to the costs in the Public Design Report have been made to allow for current conditions. Estimated operating costs are based on seven operators per shift, three shifts per day, and a burdened wage rate of $\$ 40 / \mathrm{h}$. Coal is priced at $\$ 25 /$ ton, power at $\$ 0.05 / \mathrm{kWh}$, and syngas is valued at $\$ 4.00 / \mathrm{MBtu}$. Operating costs are presented in Table 10. 
Table 10. Operating Costs for Char Production

\begin{tabular}{|c|c|}
\hline Description & Cost, $\$ / \mathbf{y r}$ \\
\hline \multicolumn{2}{|l|}{ Fixed Operating Costs } \\
\hline Operating Labor & $2,450,000$ \\
\hline Maintenance Labor & 422,700 \\
\hline Maintenance Material & 422,700 \\
\hline Supervision & 575,800 \\
\hline Miscellaneous Operating Costs & 637,000 \\
\hline Total Fixed Operating Costs & $4,508,200$ \\
\hline \multicolumn{2}{|l|}{ Variable Operating Costs } \\
\hline Coal Feed & $7,906,000$ \\
\hline Electricity & 790,600 \\
\hline Total Variable Operating Cost & $8,696,600$ \\
\hline \multicolumn{2}{|l|}{ By-product Credit } \\
\hline Syngas & $9,968,900$ \\
\hline
\end{tabular}

\section{IV.B.3 Economics}

The economics presented in Table 11 are based on a 962.4-ton/day facility with a 90-percent onstream factor. Feed-coal properties are listed in Table 1. Char yield is 0.337 ton/ton of asreceived coal.

Table 11. Economics of Char Production

\begin{tabular}{|l|c|c|c|c|c|}
\hline \multirow{2}{*}{ Item } & \multirow{2}{*}{ Base, $\mathbf{\$ 1 0}^{\mathbf{6}}$} & \multicolumn{2}{|c|}{ Current Dollars } & \multicolumn{2}{c|}{ Constant Dollars } \\
\cline { 3 - 6 } & & Factor & \$/ton char & Factor & \$/ton char \\
\hline Capital Charge & 28.18 & 0.160 & 42.31 & 0.124 & 32.79 \\
\hline Fixed O\&M Cost & 4.51 & 1.314 & 55.61 & 1.000 & 42.32 \\
\hline Variable Operating Cost & 8.70 & 1.314 & 107.30 & 1.000 & 81.63 \\
\hline By-product Credit & $(9.97)$ & 1.314 & $(122.93)$ & 1.000 & $(93.55)$ \\
\hline Levelized Cost of Char & --- & --- & 82.29 & --- & 63.19 \\
\hline
\end{tabular}


Table 11 shows that the cost of char produced by the TCI process should be about $\$ 60$ to $\$ 90 /$ ton, slightly less than the cost of coke at about $\$ 95$ to $\$ 115 /$ ton. The major factors affecting the char price are the cost of coal and labor, the value of the by-product syngas, and the capital investment. The effect of changes in these items on the cost of char is shown in Table 12.

Table 12. Sensitivity of Char Cost to Changes in Project Variables

\begin{tabular}{|l|c|c|}
\hline \multirow{2}{*}{ Description } & \multicolumn{2}{c|}{ Effect on Char Cost, \$/ton char } \\
\cline { 2 - 3 } Change in price of coal of \$1/ton & Current Dollars & Constant Dollars \\
\hline Change in labor rate of \$1/man hour & 3.90 & 2.97 \\
\hline Change in value of syngas of \$1/MBtu & 0.76 & 0.58 \\
\hline Change in Capital Requirement of \$1 million & 30.73 & 23.39 \\
\hline
\end{tabular}

Reported economics (Larson et al. 1998) for a black-liquor gasification unit producing syngas for a combined-cycle power production facility indicate that the capital cost of an oxygen-blown gasifier is about the same as for an indirectly-heated gasifier, but the power cost is somewhat lower for the indirectly-heated gasifier. Similar economics need to be performed for a facility feeding coal to substantiate the advantages of an indirectly-heated gasifier over an oxygen-blown unit. 


\section{Conclusions}

DOE's continuing role is to foster the commercialization of gasification-based processes that convert low-cost carbonaceous feed stocks to electricity, steam, fuels, chemicals, or hydrogen. As originally conceived, this project would have demonstrated a commercial-scale, indirectly heated gasifier, with heat being supplied by ten 253-tube pulse combustors. Such a project would have provided a true test of the technology. However, because of a number of circumstances, the project was significantly scaled back, so that it only involved testing one 253-tube pulse combustor installed in a sand bath and some PDU studies of coal/steam gasification.

This project provided the first step in demonstrating the TCI technology involving indirectly heated gasification using a pulsed combustor as the heat source. This project generally met its objective of demonstrating the operability of a pulsed combustor. However, because the project only involved testing one 253-tube pulse combustor installed in a sand bed and some PDU studies of coal/steam gasification, these tests, although indicating potential, do not provide enough data to make a sound judgement on possible applications of the technology. Considerably more data need to be generated to permit design of a unit for a specific situation.

Most of the applications being proposed, such as providing char for DRI and black-liquor solids destruction, are niche applications. Such applications are undoubtedly important, but cannot provide a large market for the technology with the possible exception of black-liquor destruction. There are 260 black-liquor-recovery boilers in the U.S. that could potentially be replaced (Rockvam 2002). However, each such unit would be relatively small, and this application would not involve coal usage. The only potentially large market is providing fuel gas to integrated gasification combined-cycle (IGCC) power systems. Such applications would require complete gasification of coal. Based on the information provided, it is not clear whether this technology can accomplish this or not. Much more information is required on a wide variety of coals.

The only economic data available was for a unit producing char for DRI. This analysis indicates that char can be produced by the TCI process at slightly below the cost of coke. Additional economic studies are needed, including a thorough analysis comparing the cost of an indirectlyfired gasifier with a conventional oxygen-blown gasifier. 


\section{Abbreviations and Acronyms}

$\begin{array}{ll}\text { BOD } & \text { biological oxygen demand } \\ \text { CCT } & \text { Clean Coal Technology } \\ \text { CO } & \text { carbon monoxide } \\ \text { COD } & \text { chemical oxygen demand } \\ \text { DOE } & \text { (U.S.) Department of Energy } \\ \text { DRI } & \text { direct reduction of iron ore } \\ \text { EPA } & \text { Environmental Protection Agency } \\ \text { FGD } & \text { flue-gas desulfurization } \\ \text { GC } & \text { gas chromatograph } \\ \text { IGCC } & \text { integrated gasification combined-cycle } \\ \text { IRR } & \text { internal rate of return } \\ \text { MBtu } & \text { million British thermal units per hour } \\ \text { MTCI } & \text { Manufacturing and Technology Conversion International } \\ \text { NGCC } & \text { natural gas combined cycle } \\ \text { NOx } & \text { nitrogen oxides } \\ \text { OSHA } & \text { Occupational Safety and Health Administration } \\ \text { PDU } & \text { project development unit } \\ \text { PPA } & \text { post project assessment } \\ \text { RO } & \text { reverse osmosis } \\ \text { SBIR } & \text { Small Business Innovative Research } \\ \text { SO } & \text { sulfur dioxide } \\ \text { SVOC } & \text { semivolatile organic compound } \\ \text { TCI } & \text { ThermoChem, Inc. } \\ \text { THC } & \text { total hydrocarbons } \\ \text { VOC } & \text { volatile organic compound } \\ & \end{array}$




\section{References}

Durai-Swamy, K., M.N. Mansour, and H. Said. 1994. Status of the Demonstration of Pulse Combustion in Steam Gasification. In Procceedings of the Third Annual Clean Coal Technology Conference, 6-8 September, Chicago, Illinois. Government Printing Office.

Larson, E.D., S. Consonni, and T.G. Kreutz. 1998. Preliminary Economics of Black Liquor Gasifier/Gas Turbine Cogeneration at Pulp and Paper Mills. In Procceedings of the 1998 International Gas Turbine \& Aeroengine Congress \& Exhibition, 2-5 June, Stockholm, Sweden. 98-GT-346. Fairfield, NJ: American Society of Mechanical Engineers.

Rockvam, L. 2002. ThermoChem, Inc. Private communication with H.G. McIlvried, SAIC. December.

Rockvam, L. 2003. ThermoChem, Inc. Private communication with H.G. McIlvried, SAIC. March.

ThermoChem, Inc. 1998. Steam Reforming of Low-Level Mixed Waste-Final Report. DOE/MC/32091-3. NTIS/DE98058965. Springfield,Va.: National Technical Information Service.

ThermoChem, Inc. 2000. Pulse Combustor Design Qualification Test-Test Plan.

ThermoChem, Inc. 2002a. Final Report Volume 1: Public Design-Pulse Combustor Design Qualification Test and Clean Coal Feedstock Test. OSTI/DE00794177. Springfield,Va.: National Technical Information Service.

ThermoChem, Inc. 2002b. Final Report Volume 2: Project Performance and Economics-Pulse Combustor Design Qualification Test and Clean Coal Feedstock Test. OSTI/DE00794177. Springfield,Va.: National Technical Information Service.

Turdera, J., and R.L Zahradnik. 1992. Feasibility Evaluation and Conceptual Design of a Pulse Tube Combustion System for a Commercial Scale Integrated Coal Gasification Combined Cycle (IGCC) Power Plant.

U.S. Department of Energy. 1992. Comprehensive Report to Congress--Clean Coal Technology Program--Demonstration of Pulse Combustion in an Application for Steam Gasification. NTIS/DE93000959. Springfield,Va.: National Technical Information Service. 


\section{Bibliography}

Durai-Swamy, K., M.N. Mansour, H. Said, W.G. Steedman, G. Clayton, and K.Vesperman.1993. Status of the Demonstration of Pulse Combustion in Steam Gasification. In Proceedings of the Second Annual Clean Coal Technology Conference, 7-9 September, Atlanta, Georgia. DE94004473. Springfield,Va.: National Technical Information Service.

Mansour, M.N., W.G. Steedman, and R.E. Kazares. 1992. Demonstration of PulseEnhanced ${ }^{\mathrm{TM}}$ Steam Reforming in an Application for Gasification of Coal. In Proceedings of First Annual Clean Coal Technology Conference, 22-24 September, Cleveland, Ohio. DE93004314. Springfield,Va.: National Technical Information Service. 